To cite this article:

Wu P., Xu Y.,Jin R.*, Lu Q., Madgwick D., and Hancock C. (2018). "Perceptions towards Risks involved in Off-site Construction in theIntegrated Design \& Construction Project Delivery." Journal of Cleaner Production, accepted on 20 December, 2018.

\title{
Perceptions towards Risks involved in Off-site Construction in the Integrated \\ Design \& Construction Project Delivery
}

- The research focuses on adopting IDC (i.e., integrated design and construction) approach in OSC (i.e., off-site construction) projects.

- Design experience of architects and engineers in OSC was considered most critical risk factor.

- Professionals' experience in IDC and in OSC affected their risk perceptions.

- IDC experience was found more influential in affecting risk perceptions compared to OSC experience.

- Those with less experience in OSC or in IDC tended to perceive risks with higher degrees of significance.

\begin{abstract}
This study aimed to address the gap in research regarding the application of integrated design and construction (IDC) project delivery into off-site construction Projects (OSC) within China. A questionnaire survey was designed and delivered to reach Chinese professionals in Architecture, Engineering, and Construction (AEC) disciplines to assess their risk perceptions. Risk was considered in terms of probability and severity. Two main research hypotheses were proposed that AEC professionals' perceptions towards applying IDC in OSC projects would be affected by their experience in OSC or in IDC. Based on a total of 112 valid questionnaire responses, statistical analyses were conducted, including the relative importance index analysis, internal consistency analysis involving Cronbach's Alpha, the one-way analysis of variance, and post-hoc tests. It was indicated that AEC practitioners' experience in both OSC and IDC did affect their perceptions towards the risks. It was further identified that compared to professionals' OSC experience, their
\end{abstract}


experience or knowledge in IDC played a more significant role in affecting their risk perceptions. Those with little experience in OSC or IDC tended to perceive risks with a higher degree of significance. This study contributes to the body of knowledge in terms of integrating OSC with IDC, by addressing the research question of whether the experience level in OSC and in IDC would impact AEC professionals' risk perceptions. Future research could continue this study by adopting empirical case studies to evaluate risks when applying IDC in OSC projects.

Keywords: Off-site construction; integrated design and construction; project delivery method; subgroup analysis; risk perception; China.

\section{Introduction}

Off-site construction (OSC) is a new construction method that moves the building process from the physical jobsite into a controlled factory environment (Jiang et al., 2018; Mostafa and Chileshe, 2018). It has been recognized as the way to transform the construction sector from a labour-intensive to a modernized green industry (Gan et al., 2018) and considered a sustainable practice in the construction industry (Ma et al., 2018). OSC can reduce project duration, reduce waste, enhance safety performance, and improve the project quality (Tam et al., 2015; Li et al., 2016; Chen et al, 2017). As one of the main economic contributor, China's construction industry has been undergoing a high growth rate in recent decades (Ji et al., 2017). The traditional in-situ construction approach is causing challenges to China such as carbon emission (Wang et al., 2016) and overwhelmed waste generated (Yuan, 2013). The new urbanization movement in China is causing more resource consumption especially in the construction industry (Fernández, 2008) due to the growing housing demand. China could benefit from OSC in terms of improving the environmental sustainability, achieving higher project quality, and enhancing construction innovation (Mao et al., 
2016). However, there are several barriers in promoting OSC in China's architecture, engineering, and construction (AEC) industry, such as higher initial project cost (Hong et al., 2018), lack of knowledge or expertise (Gan et al., 2018), and absence of government regulation and incentives (Mao et al., 2013).

In recent years, practitioners (e.g., Jiang et al., 2015; Wang et al., 2015; Zhao, 2017) in China's construction industry recommended the incorporation of integrated design \& construction (IDC) such as Design-Build project delivery method in OSC projects. Governmental authorities such as Shanghai Housing and Urban and Rural Construction Management Committee (i.e., SHURCMC, 2016) also suggested that OSC be implemented under the IDC project delivery approach (e.g., Design-Build). A review of the recent years' research and practice in OSC revealed several gaps, including: 1) there have been limited studies focusing on the risk perceptions of professionals towards potential barriers despite that these barriers having been identified in previous studies (e.g., Zhang et al., 2014); 2) existing studies (e.g., Wang et al., 2018) targeting on risk evaluation for China's OSC projects have not linked OSC in the IDC context; 3) there have also been insufficient studies targeting on OSC practice under the IDC approach; and further 4) there have been limited investigations on whether professionals ' experience would affect their risk perceptions towards OSC. The collaborative management among stakeholders has a significant impact on OSC project performance (Gan et al., 2018a; Xue et al., 2018). It is likely that project team members would have different experience levels in OSC. The experience levels in OSC could affect stakeholders' perceptions towards barriers in OSC projects (Rahman, 2014). Therefore, studying the effects of experience levels on practitioners' perceptions towards risks involved in OSC is important for enhancing the stakeholders' collaboration. 
This study aims to investigate the risk perceptions of professionals towards OSC when adopting the IDC approach in China, the objectives of this study are: 1) to define major risk items involved in adopting OSC in China 2) to unveil the overall risk perceptions of OSC practice among Chinese practitioners; and 3) to investigate the subgroup variations of perceptions towards OSC practice adopting the IDC approach. Subgroups in this study were defined according to practitioners experience levels in OSC or in IDC approach. Risks in this study were measured according to their probability of occurrence, severity, and risk score

\section{Literature review}

\subsection{Implementation of OSC in China}

Zhang et al. (2014) reviewed the historical movement of industrialized building in China since 1950s. The use of precast building components has been increasing in China since the middle 2000s due to the rapid development of the national economy, growing labour costs, and increased demand for environmental sustainability (Zhang et al., 2014). In recent years, the Chinese government has put forward the modernized, productive, and environmentally-sustainable concepts in its new-urbanization movement (Mu, 2015). The State Council of China (2016) has also highlighted the importance of promoting OSC for the industry and set the goal that $30 \%$ of new buildings should adopt an OSC approach in the following decade. It has become mandatory to adopt OSC for affordable housing development in several metropolitan cities such as Beijing, Shenzhen, and Chongqing (Gan et al., 2018b). To echo the national strategy of promoting OSC, the industry practitioners and regional construction authorities have being exploring the workable measures in implementing prefabricated construction. For example, pilot residential construction project has reached the prefabrication rate between $50 \%$ and $70 \%$ in Shanghai (SHURCMC, 
2016). Despite the fast movement and active promotion from the government, the development of OSC in China is still in the early stage as indicated by Hong et al. (2018). According to Mao et al. (2016), the projected market share of OSC in China remained below $2 \%$ in China's construction sector, far below the national target. Multiple barriers and risks could be encountered in implementing OSC in China, such as incomplete relevant policies and standards (Jiang et al., 2018).

\subsection{OSC and IDC-featured project delivery}

The underlying interrelationships and the interaction effects of the activities should be considered in adopting OSC ( $\mathrm{Li}$ et al., 2014). These interactions in OSC involve the multi-stakeholder collaboration (Xue et al., 2018), project planning and design (Hosseini et al, 2018b), as well as information sharing among multiple project parties throughout the process of design, manufacturing, storage, transportation, and site assembly ( $\mathrm{Li}$ et al., 2016). Integrated project delivery (IPD) could be a potential approach to overcome the fragmented feature in traditional construction (Nawi et al., 2014). Inadequate use of resources and schedule delay have been an issue in OSC (Kong et al., 2017).

IPD was suggested by Grosskopf et al. (2017) as one managerial strategy to enhance the OSC practice, as IPD could improve the multi-party collaboration throughout the fabrication, transportation, and construction of off-site projects (Osman et al., 2015). Besides IPD, other fast-track project delivery methods (e.g., Design-Build) could also provide the systematic support to OSC implementation (Jin et al., 2018). Using Design-Build as an example of IDC project delivery method, there is one single-entity namely Design-Build team (Bogus et al., 2013) to provide the design and construction services to the client. Compared to the more traditional design-bid-build procurement, the procurement of design and construction in IDC 
approach (e.g., Design-Build or Construction Management at Risk) tends to focus more on quality rather than bidding price (Jin, 2010). Jin et al. (2018) stated that limited studies have addressed the inter-relatedness between the project delivery system and OSC.

\subsection{Risks involved in OSC projects}

Although OSC is expected to improve the sustainability performance and increase the housing affordability (Mostafa et al., 2014b), barriers encountered in OSC implementation have also raised the concern, for example, increased design complexity brought by off-site manufacturing leading to slower responses to customer demands (Mostafa et al., 2014a) and the barriers for OSC to achieve lean (Mostafa et al., 2016). As a result, risks involved in OSC projects as compared to conventional site-cast project cannot be downplayed. These risks include, but may not be limited to:

- insufficiently developed laws, policies, and standards for OSC (Jiang et al., 2018a; Jiang et al., 2018b);

- uncertainty in engineering performance of OSC projects due to lack of technical standards (Minghini et al., 2016);

- the lack of design code could lead to more specific concerns in the design stage in OSC projects, such as the performance of connections between prefabricated structural components (Vaghei et al., 2016);

- the risk in design uncertainty of joints between prefabricated components could lead to further risks in construction quality (Liao, 2018);

- OSC design inadequately accommodating the local condition such as supply chain management (Zhang et al., 2014; Hong et al., 2018); 
- insufficient knowledge or experience of industry professionals in the design, construction, or management of OSC projects (Luo et al., 2017);

- inadequate communication among OSC project teams such as lack of coordination between architects and contractor (Luo et al., 2015; Ismail et al., 2016; Pozin et al., 2017);

- Higher initial cost (Mao et al., 2013; Mao et al., 2016)

Among these factors, Luo et al. (2015) identified these five risks more critical, namely: "poor cooperation between multi-interface," "inappropriate design codes and standards for industrialized buildings," "lack of management practices and experiences," "enormous difficulty in achieving return on high initial investment," as well as "lack of a quality monitoring mechanism for the production process." All these aforementioned risk items in OSC projects were also recognized by Mao et al. (2013), with other risks also identified, for instance, improper storage or site layout of prefabricated components, the regular need for mobile crane to lift large load components, durability of prefabricated components, damage of prefabricated elements during transportation, and lack of quality monitoring on prefabricated components.

\subsection{Risks encountered in IDC project delivery}

Despite of the potential benefits of adopting IDC approach in construction projects, such as improved project performance in cost and scheduling (Konchar and Sanvido, 1998), risks involved in IDC projects should also be noticed. These risks could include:

- decision-making in the procurement stage for the owner (Ling et al., 2004), such as uncertainties of developing the procurement strategies to the design and 
construction teams (e.g., Design-Build firm) according to the procedure described by Mialiaccio et al. (2009);

- teamwork and partnering in the IDC approach as emphasized by Chan et al. (2001), for example, different working methods among partners (Bing et al., 2005);

- lack of experience of the project team members in IDC (Bing et al., 2005), which could result in reservations of multiple stakeholders about adopting IDC as indicated by Kent and Becerik-Gerber (2010);

- the uncertainty of how IDC approach would affect supply chain, and further including the final project performance as indicated by Mesa et al. (2016).

More risks involved in IDC-featured project delivery could be found in the existing literature, such as stakeholders' reluctance with change from traditional delivery method, lack of qualified personnel within the organization to handle IDC approach, and the owner's loss of control of the design process as described by Shrestha et al. (2016).

\section{Methodology}

\subsection{Definition of risks involved in OSC projects}

Potential risk items involved in OSC projects in China were identified by comprehensive literature review and then placed into categories of general risks, design-related risks, construction-related risks, as well as people and organization-related risks.

The workflow to determine the risk items for OSC projects in IDC project delivery is illustrated in Fig.1. 


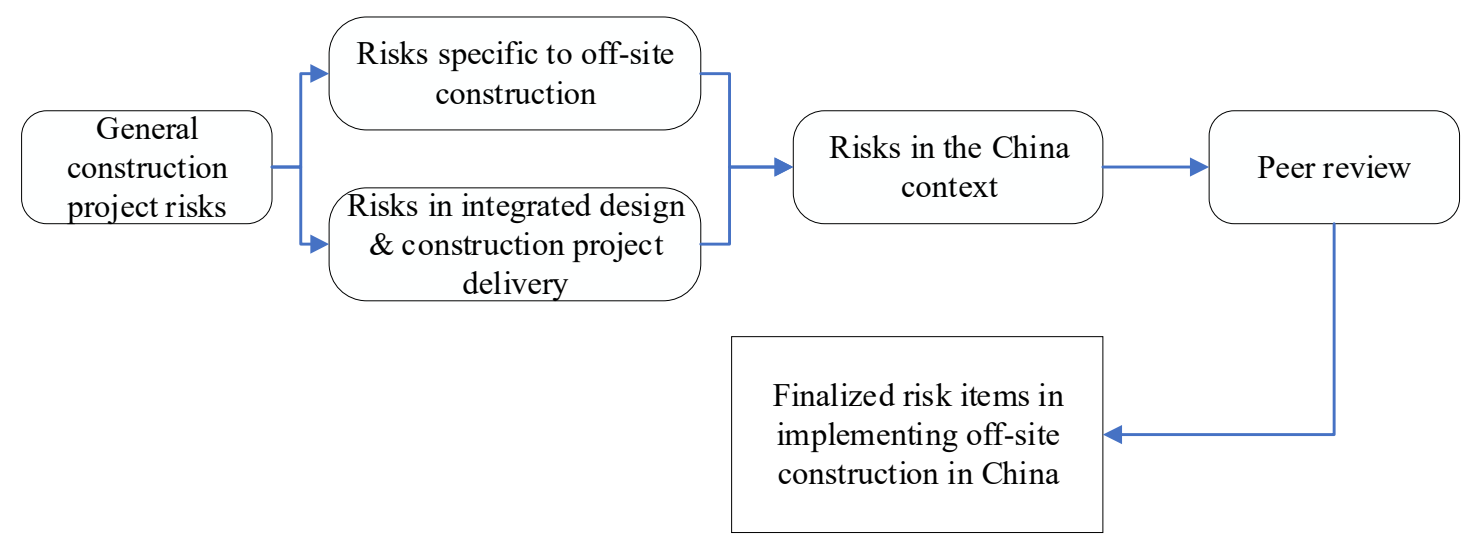

Fig.1. Steps to determine the risk items of implementing OSC

General project risks in the construction industry were reviewed at the beginning. For example, Akintoye et al. (1997) identified the construction project risks came from environmental, design, construction, and organizational issues. Yang (2011) provided a total of 84 risk items involved in overseas construction projects, such as personnel, organizational, social, and technical risks. When focusing on specifically on the OSC projects, multiple risks were identified, such as lack of government incentives, directives, or promotion (Nawi et al., 2011), lack of supply chain (Chiang et al., 2006), lack of codes and standards (Kamar et al., 2009), inflexibility of design (Swierk, 2005), and limited site storage space for prefabricated components (Tam et al., 2007). On the other hand, risks involved in the IDC project delivery (e.g., Design-Build) shared some of the main categories, including political, social, environmental, financial, technical, management, and organizational aspects summarized by He (2008).

Based on the risks identified in prior literature review (i.e., risks in OSC projects and risks involved in IDC delivery approach), the follow-up step was to integrate the risk factors between OSC and IDC for this study in China. It was indicated by Gan et al. (2018b) that barriers and risks in adopting OSC might vary between countries. Therefore, it was important to tailor the initially defined risk items in the China 
context. For example, the local supply chain could vary significantly between different regions of China (Hong et al., 2018) and the project delivery for OSC should consider the local supply chain conditions. The peer review process involved two academics and two industry practitioners in China's AEC industry to ensure that the initiated items were clearly described and representing the typically critical issues in China's OSC sector. Following the workflow illustrated in Fig.1, a total of 14 key risk items were finalized as displayed in Table 1.

Table 1. Finalized list of risk items associated with implementing OSC in IDC project delivery

\begin{tabular}{|c|c|c|c|}
\hline Category & Risk item & Description & $\begin{array}{l}\text { Reference in } \\
\text { the China } \\
\text { context }\end{array}$ \\
\hline \multirow[t]{2}{*}{ General risks, } & $\begin{array}{l}\text { GR1: law, policy, and } \\
\text { regulation }\end{array}$ & $\begin{array}{l}\text { Insufficiently developed regulation and policies } \\
\text { to promote OSC(e.g., lack of incentive policy } \\
\text { from the government) }\end{array}$ & $\begin{array}{l}\text { Ji et al. (2017); } \\
\text { Gan et al. } \\
\text { (2018) }\end{array}$ \\
\hline & $\begin{array}{l}\text { GR2: resilience } \\
\text { performance }\end{array}$ & $\begin{array}{l}\text { Uncertainty of prefabricated structure in resisting } \\
\text { natural disasters and its resilience performance }\end{array}$ & $\begin{array}{l}\text { Jiang et al. } \\
(2018)\end{array}$ \\
\hline \multirow[t]{5}{*}{$\begin{array}{l}\text { Design- } \\
\text { related risks }\end{array}$} & $\begin{array}{l}\text { DR1: design } \\
\text { incorporating the } \\
\text { local condition }\end{array}$ & $\begin{array}{l}\text { Insufficient consideration of the local supply } \\
\text { chain condition in the design stage }\end{array}$ & $\begin{array}{l}\text { Hong et al. } \\
(2018)\end{array}$ \\
\hline & $\begin{array}{l}\text { DR2: design } \\
\text { experience of } \\
\text { architects and } \\
\text { engineers }\end{array}$ & $\begin{array}{l}\text { Insufficient experience of architects and } \\
\text { engineers in designing for prefabricated } \\
\text { buildings, such as utilizing BIM for design }\end{array}$ & Liao (2018) \\
\hline & $\begin{array}{l}\text { DR3: interdisciplinary } \\
\text { design coordination } \\
\text { for prefabricated } \\
\text { components }\end{array}$ & $\begin{array}{l}\text { Lack of detailed design meeting multi-party } \\
\text { needs in the pre-construction stage (e.g. design } \\
\text { coordination between structural and plumbing } \\
\text { systems)) }\end{array}$ & Zhao (2017) \\
\hline & $\begin{array}{l}\text { DR4: design code for } \\
\text { standardized modular } \\
\text { components }\end{array}$ & $\begin{array}{l}\text { Lack of standards for modular members that can } \\
\text { be adopted consistently in the design and } \\
\text { construction across projects }\end{array}$ & $\begin{array}{l}\text { China } \\
\text { Construction } \\
\text { News (2016); } \\
\text { Chu et al., } \\
(2017)\end{array}$ \\
\hline & $\begin{array}{l}\text { DR5: joint design for } \\
\text { connecting off-site } \\
\text { components }\end{array}$ & $\begin{array}{l}\text { Lack of well-established design code or standard } \\
\text { for joints to connect modular components on-site }\end{array}$ & Ji et al. (2013) \\
\hline \multirow[t]{3}{*}{$\begin{array}{l}\text { Construction- } \\
\text { related risks }\end{array}$} & $\begin{array}{l}\text { CR1: site storage and } \\
\text { security for off-site } \\
\text { manufactured } \\
\text { components }\end{array}$ & $\begin{array}{l}\text { Lack of properly planned storage space causing } \\
\text { extra issues such as higher transportation cost and } \\
\text { security of modular components }\end{array}$ & $\begin{array}{l}\text { Jiang et al., } \\
\text { (2015); Wang et } \\
\text { al. (2015) }\end{array}$ \\
\hline & $\begin{array}{l}\text { CR2: safety and } \\
\text { function of temporary } \\
\text { structures on-site }\end{array}$ & $\begin{array}{l}\text { The gap between the needs for temporary } \\
\text { structures to precisely assembly modular } \\
\text { components and the functional quality of existing } \\
\text { temporary structures }\end{array}$ & $\begin{array}{l}\text { Tian (2014); } \\
\text { Jiang et al. } \\
(2016)\end{array}$ \\
\hline & $\begin{array}{l}\text { CR3: construction } \\
\text { quality specification } \\
\text { for joints }\end{array}$ & $\begin{array}{l}\text { The lack of specifications for quality assurance } \\
\text { and quality control of joints between modular } \\
\text { components (e.g. the strength of site-cast concrete } \\
\text { in the joints to connect precast concrete members }\end{array}$ & $\begin{array}{l}\text { Chang and Fan } \\
\text { (2016); Jiang et } \\
\text { al. (2016); Liao } \\
\text { (2018) }\end{array}$ \\
\hline
\end{tabular}




\begin{tabular}{|c|c|c|c|}
\hline \multirow[t]{4}{*}{$\begin{array}{l}\text { People and } \\
\text { organization- } \\
\text { related risks }\end{array}$} & $\begin{array}{l}\text { POR1: Experience of } \\
\text { employees in } \\
\text { OSCprojects }\end{array}$ & $\begin{array}{l}\text { Lack of experience or proper training for } \\
\text { management personnel, technicians, and workers } \\
\text { to work in OSCprojects }\end{array}$ & $\begin{array}{l}\text { Jiang et al. } \\
(2015) \text {; Guo and } \\
\text { Zhang (2017) }\end{array}$ \\
\hline & $\begin{array}{l}\text { POR2: management } \\
\text { risks during the } \\
\text { project execution } \\
\text { process }\end{array}$ & $\begin{array}{l}\text { Failure of on-time delivery of prefabricated } \\
\text { components or improper site coordination leading } \\
\text { to inferior construction quality, delayed } \\
\text { completion date, or increased cost }\end{array}$ & $\begin{array}{l}\text { Jiang et al. } \\
\text { (2015); Guo and } \\
\text { Zhang (2017) }\end{array}$ \\
\hline & $\begin{array}{l}\text { POR3: Coordination } \\
\text { and communication } \\
\text { among project team } \\
\text { members }\end{array}$ & $\begin{array}{l}\text { Insufficient communication and collaboration } \\
\text { among multiple project parties during the design, } \\
\text { manufacturing, transportation, and site assembly } \\
\text { workflow }\end{array}$ & $\begin{array}{l}\text { Yan et al. } \\
(2014) \text {; Wang et } \\
\text { al. (2015) }\end{array}$ \\
\hline & $\begin{array}{l}\text { POR4: proper } \\
\text { maintenance of } \\
\text { modular components }\end{array}$ & $\begin{array}{l}\text { Improper maintenance and protection in the } \\
\text { post-manufacturing stage leading to deteriorating } \\
\text { engineering properties of modular components }\end{array}$ & Su et al. (2016) \\
\hline
\end{tabular}

\subsection{Questionnaire survey}

Risk identification forms a fundamental part of risk management, and plays a key role leading to risk assessment (Hallikas et al., 2004; He et al. 2008). Probabilistic risk estimated by individuals is subjective due to the influence of social, institutional and cultural factors (Slovic, 1992). With appropriate survey instruments, risk factors or items could be quantified to measure individual responses (Slovic, 1992). In this study, individual risk perceptions were measured through a questionnaire survey approach. The questionnaire survey was designed during January and March of 2018. It comprised of two main parts. The first part which was multiple choice focused on the professional background, experience in OSC projects and IDC project delivery, as well as general opinions of survey participants coming from China's AEC industry. In the second part of the questionnaire, five-point Likert scale questions were initiated to measure AEC professional's risk perceptions towards the 14 defined items listed in Table 1. The five-point Likert scale was adopted to measure the risk perceptions based on the rationales that: (1) it was typically adopted in the field of construction project management especially in risk assessment and management, examples can be found in Chileshe and Kikwasi (2014b), Chileshe et al. (2016), Hosseini et al. (2016a), and Hosseini et al. (2016b); (2) it was also commonly adopted to investigate key issues in OSC projects, such as constraints (Jiang et al., 2018), risk assessment (Mao 
et al., 2015), and sustainability performance (Yunus and Yang, 2014); and (3) most importantly, according to the rationale provided by Zou and Zhang (2009) and Zhang et al. 2013), both the probability and the severity of risk items could be measured by a five-point scale. For example, in the study of Zhang et al. (2013), the five-point Likert Scale for the probability was measured as: 1 indicating "very low", 2 meaning "low", 3 being "average", 4 referring to "high", and 5 indicating "very high". Similarly, the severity of risks was measured by Zhang et al. (2013) and Mao et al. (2015) with 1 being "slight or little effect", 2 meaning "some loss", 3 indicating "bad", 4 meaning "very bad", and 5 meaning "worst".

Risk identification aims to catch the key information including the probability and severity of the target risk (He et al., 2008). Two five-point Likert-scale questions were applied to measure the probability and severity of the risk items in Table 1 . The five-point scales for risk probability and severity were employed following the guide provided by Chen (2015) and Ding and Xu (2018). Table 2 provides the description of scale directions.

Table 2. Measurements of risk probability and severity using five-point Likert scales following the guide of Chen (2015) and Ding and Xu (2018).

\begin{tabular}{|c|l|l|}
\hline $\begin{array}{c}\text { Risk scale for } \\
\text { probability }\end{array}$ & Description & Detailed measurement \\
\hline 1: almost impossible & $\begin{array}{l}\text { It is generally assumed that the } \\
\text { given risk will not happen. }\end{array}$ & Likelihood bellow $0.03 \%$ \\
\hline 2: Unlikely & $\begin{array}{l}\text { This risk is with low probability to } \\
\text { occur. }\end{array}$ & $\begin{array}{l}\text { Likelihood between } 0.03 \% \text { and } \\
0.3 \%\end{array}$ \\
\hline 3: Occasionally & This risk might occur. & Likelihood between $0.3 \%$ and 3\% \\
\hline 4: Likely & $\begin{array}{l}\text { This risk happened a few times in } \\
\text { previous projects. }\end{array}$ & Likelihood between 3\% and 30\% \\
\hline 5: Often & $\begin{array}{l}\text { This risk has been occurring } \\
\text { frequently. }\end{array}$ & Likelihood over 30\% \\
\hline Risk scale for severity & \multicolumn{1}{|c|}{ Description } \\
\hline 1: Negligible & This risk, if occurring, can be considered with little loss. \\
\hline 2: Less significant & $\begin{array}{l}\text { This risk, if occurring, could cause some losses, such as affordable } \\
\text { project delay, injuries, or cost to cover the loss. }\end{array}$ \\
\hline 3: Significant & $\begin{array}{l}\text { This risk, if occurring, would cause some significant losses, such as } \\
\text { somewhat serious delay or increased cost. }\end{array}$ \\
\hline 4: Critical & This risk, if occurring, would cause serious issues to project success, such \\
\hline
\end{tabular}




\begin{tabular}{|c|l|}
\hline & $\begin{array}{l}\text { as serious health and safety issues, unable to complete the project as } \\
\text { originally scheduled, or serious cost overrun. }\end{array}$ \\
\hline 5: Disastrous & $\begin{array}{l}\text { This risk, if occurring, would cause fatalities, bankrupt, crime, or project } \\
\text { failure. }\end{array}$ \\
\hline
\end{tabular}

The definitions of the numerical options were also provided for survey participants in the questionnaire attached in the Appendix.

On-line surveys were sent out during May and June of 2018 targeting Chinese professionals in the network of architecture and construction engineering. Survey participants were provided with the consent and the explanation of the survey purpose in terms of perceiving risks in implementing OSC projects adopting IDC project delivery approach. Potential survey participants were aware that no personal or company information would be collected during the survey, and they could decide to either accept the survey, quit in the middle of the survey, or complete the survey to the best of their knowledge.

\subsection{Statistical analysis}

Following the questionnaire survey, the data was collected for follow-up statistical analysis. The statistical analysis aimed to address two main research hypotheses: 1) Professionals' perceptions towards the risks involved in OSC projects adopting IDC approach were affected by their experience level in OSC projects; and 2) Professionals' perceptions towards the same risks were also affected by their experience level in participating in IDC project delivery approach.

The risks encountered in OSC projects adopting IDC approach were measured by three categories, namely the probability, severity, and risk score of each given risk item. The probability and severity were measured by the Likert-scale numerical score from the questionnaire survey. The risk score of each risk item in Table 1 was calculated based on the product of probability and severity using Equation (1):

$$
\text { Risk score }=\sqrt{\text { Probability } * \text { Severity }}
$$


It is indicated from Equation (1) that the risk score of each risk item has the same range from 1 to 5 . Multiple statistical methods were then adopted in analyzing the survey responses besides the prescriptive statistics (i.e., mean and standard deviation of Likert-scale risk items). These methods included the relative importance index (RII) analysis, internal consistency analysis involving Cronbach's Alpha, the one-way analysis of variance (ANOVA), and post-hoc tests.

The RII value of each risk item was calculated using the same formula provided by Eadie et al. (2013). Ranging from 0 to 1, a higher RII score would indicate a higher significance of the risk item in practicing OSC projects adopting IDC approach.

The internal consistency was measured by Cronbach's Alpha value (Cronbach, 1951), which ranged from 0 to 1. A higher Cronbach's Alpha value indicates that a survey respondent who has selected a Likert-scale score to one risk item would be more likely to choose a similar score. An overall Cronbach's Alpha value from 0.70 to 0.95 would be considered satisfied with fair internal interrelatedness (DeVellis, 2003). Besides the overall Cronbach's Alpha value, an individual value was also computed for each risk item in the same question (e.g., probability). The individual value is generally lower than the overall Cronbach's Alpha value, indicating that the given risk item contributes positively to the internal consistency of the same question. Otherwise, an individual value higher than the overall one would mean that survey respondents perceive differently towards this given risk item as compared to what they would normally view the remaining items. Corresponding to every individual Cronbach's Alpha value, there is an item-total correlation that demonstrates the correlational relationship between the given risk item and the remaining items.

ANOVA was adopted as the parametric method to compare the Likert-scale questions among subgroups divided according to either survey respondents' level of 
experience in OSC projects or their experience in IDC project delivery approach. Parametric methods have been proved of their robustness (e.g., Carifio and Perla, 2008; Norman, 2010) in analyzing data samples that were either small or not normally distributed. Studies such as Tam (2009) and Xu et al. (2018) have applied parametric methods in the field of construction engineering and management in evaluating survey data from questionnaires. The null hypothesis of ANOVA was that AEC professionals from different levels of experiences in OSC or IDC held consistent perceptions towards the given risk item. A $F$ value and a corresponding $p$ value were computed for each risk item under each risk category (i.e., probability, severity, or risk score). Based on the level of significance at $5 \%$, a $p$ value lower than 0.05 would reject the null hypothesis and support the research hypothesis that survey respondents' perceptions towards the given risk item is affected by their level of experience in OSC or IDC.

Following ANOVA, post-hoc tests were performed to further identify the significant differences between pairs of subgroups. Post-hoc tests could confirm where the significant differences occur among groups (Laerd Statistics, 2018). Two types of post-hoc methods were adopted in the statistical analysis, namely Tukey Simultaneous and Fisher Individual. Both of them were conducted based on the 95\% Confidence Intervals (CI). The Tukey's test was suitable for exploring which subgroups differ from the overall sample by comparing the mean values, and the Fisher's test could identify which pairs of means were statistically different (Statistics How To, 2018). More details of applying Tukey Simultaneous and Fisher Individual in the field of construction management can be found in Han et al. (2018).

\section{Results and findings}


By the end of June 2018, out of the 1,189 on-line questionnaire surveys a total of 189 responses were received. Excluding those incompletely filled questionnaires and those who chose the same answers for all Likert-scale items within the same question following the screening procedure suggested by Smits et al. (2017), finally a total of 112 completed valid questionnaires were adopted for the follow-up data analysis.

\subsection{Background of survey participants}

The professional background of survey participants is summarized in Fig.2.

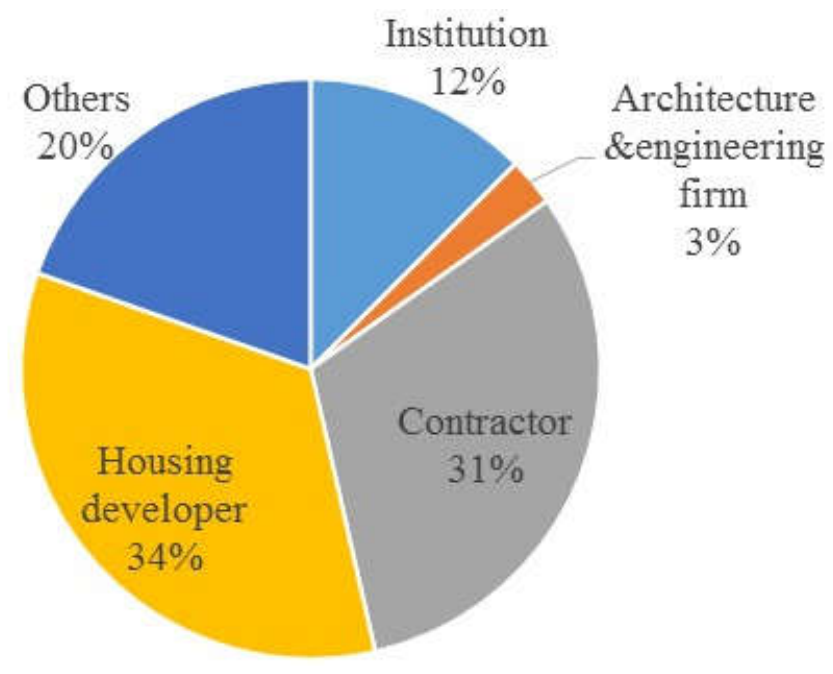

Fig.2. Professional background of survey participants in this study $(\mathrm{N}=112)$

Other professional organizations in Fig.2 included governmental authorities, quality inspections, and material testing. The overall sample was then divided according to their levels of experience in OSC and IDC. As displayed in Fig.3, four different levels of OSC from EOSC1 to EOSC4 were defined. Similarly, another four levels of IDC experience were defined from EIDC1 to EIDC4. 


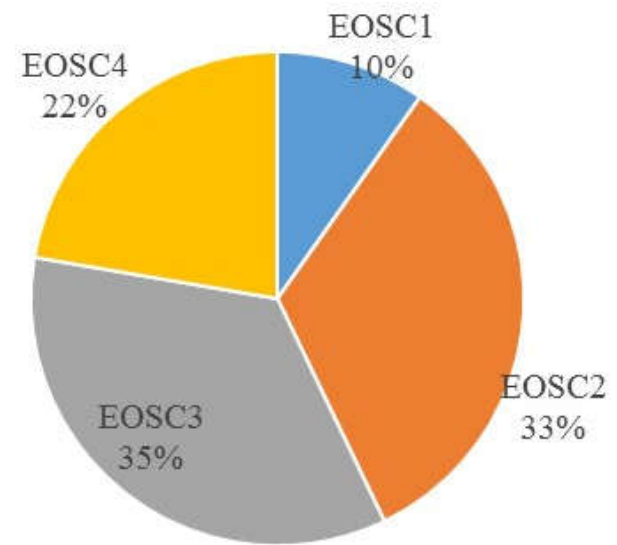

EOSC1: with sufficient practical experience working in OSC projects

EOSC2: with certain knowledge but limited practices in OSC projects

EOSC3: with limited knowledge in OSC projects EOSC4: Little knowledge or experience in OSC

a) Percentages of survey respondents from different experience levels in OSC

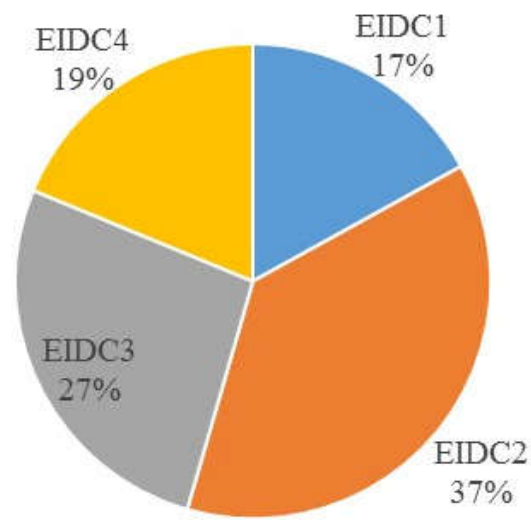

EIDC1: with sufficient practical experience working in IDC project delivery

EIDC2: with certain knowledge but limited practices in IDC project delivery

EIDC3: with limited knowledge in IDC projects

EIDC4: Little knowledge or experience in IDC

b) Percentages of survey respondents from different experience levels in IDC

Fig.3. Professional experience of survey participants in terms of OSC projects and IDC project delivery $(\mathrm{N}=112)$

Consistent to what was indicated by Hong et al. (2018) that China was still in the early stage of developing OSC. The majority of survey participants in this survey had limited experience or knowledge in OSC. A slightly higher percentage of survey participants had practical experiences in the IDC approach according to Fig.3.

\subsection{General perceptions towards OSC and IDC applied in OSC}

Survey participants were further asked with two general perceptions regarding whether OSC would be more widely applied in China's building sector, as well as how applying the IDC approach in OSC would affect project risks. Fig.4 lists the percentages survey participants who selected each option. 


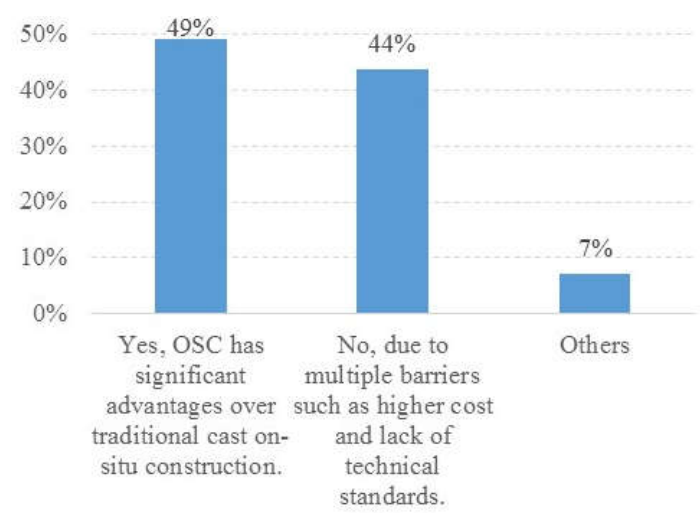

c) Responses to the question of whether OSC should be widely applied in China's building sector

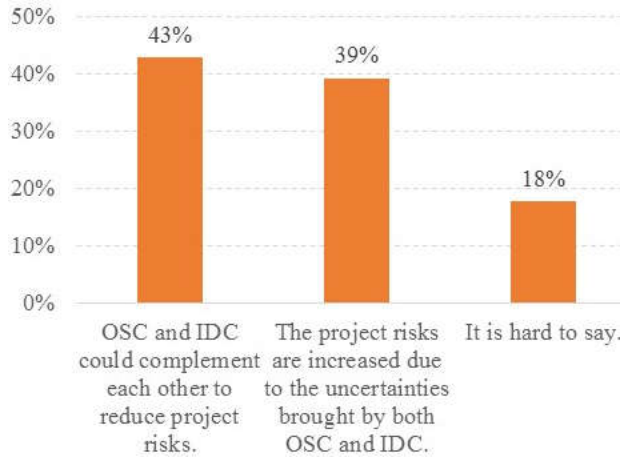

d) Responses to the question of applying IDC in OSC

Fig.4. General perceptions of survey participants in terms of OSC projects and IDC applied in OSC

Those who chose "others" in the question of whether OSC would be more widely applied were asked to provide further details. These detailed responses included:

- the OSC technology was not ready and implementing OSC in China still had higher risks;

- OSC might not be ready currently. But it could gain a wider application in the long run;

- whether or not to apply OSC in building projects depended on the project size and the specific project requirements;

- the government was actively promoting the implementation of OSC projects;

- it remained unsure whether OSC should be promoted.

Fig.4 indicates that survey respondents held generally varied perceptions of the visions of OSC movement. The percentages of respondents who chose positive and conservative views of OSC in China were not significantly different. Similarly, not a single option dominated the responses regarding how applying IDC in OSC projects would affect project risks.

\subsection{Probability of risks involved in implementing OSC in the IDC project delivery}


A further analysis of the survey sample's perceptions towards multiple risk items identified in Table 1 was then conducted. The varied general perceptions indicated in Fig.4 also motivated the exploration of potential causes of variations among the overall survey population. Table 3 summarizes the overall perception of survey participants towards the probability of occurrence of risk items.

Table 3. Statistical analysis of survey participants towards the probability of risks involved in OSC in the IDC project delivery (overall Cronbach's Alpha value = $0.8779)$

\begin{tabular}{|l|c|c|c|c|c|c|}
\hline Risk item & $\begin{array}{c}\text { Item-total } \\
\text { Correlation }\end{array}$ & $\begin{array}{c}\text { Cronbach's } \\
\text { Alpha }\end{array}$ & Mean & $\begin{array}{c}\text { Standard } \\
\text { Deviation }\end{array}$ & $\boldsymbol{R I I}$ & Ranking \\
\hline GR1 & $\mathbf{0 . 3 5 2 0}$ & $\mathbf{0 . 8 7 9 3}$ & 1.839 & 0.800 & 0.368 & 13 \\
\hline GR2 & 0.5098 & 0.8713 & 1.795 & 0.761 & 0.359 & 14 \\
\hline DR1 & $\mathbf{0 . 3 6 5 3}$ & $\mathbf{0 . 8 7 8 0}$ & 2.482 & 0.747 & 0.496 & 10 \\
\hline DR2 & $\mathbf{0 . 3 8 7 0}$ & $\mathbf{0 . 8 7 8 9}$ & 2.991 & 0.895 & 0.598 & 1 \\
\hline DR3 & 0.5611 & 0.8690 & 2.607 & 0.702 & 0.521 & 3 \\
\hline DR4 & 0.6460 & 0.8647 & 2.580 & 0.755 & 0.516 & 6 \\
\hline DR5 & 0.6207 & 0.8661 & 2.625 & 0.724 & 0.525 & 2 \\
\hline CR1 & 0.5777 & 0.8681 & 2.607 & 0.727 & 0.521 & 3 \\
\hline CR2 & 0.6122 & 0.8661 & 2.607 & 0.809 & 0.521 & 3 \\
\hline CR3 & 0.6189 & 0.8664 & 2.438 & 1.020 & 0.488 & 12 \\
\hline POR1 & 0.6105 & 0.8667 & 2.527 & 0.710 & 0.505 & 9 \\
\hline POR2 & 0.6738 & 0.8641 & 2.473 & 0.684 & 0.495 & 11 \\
\hline POR3 & 0.5320 & 0.8703 & 2.536 & 0.709 & 0.507 & 8 \\
\hline POR4 & 0.6555 & 0.8651 & 2.545 & 0.670 & 0.509 & 7 \\
\hline
\end{tabular}

Note: bold values in Table 3 indicate that survey participants tended to hold different perceptions towards the given risk item as they would do to other items. The same rule applies to other follow-up tables regarding the Item-total Correlation and Cronbach's Alpha.

The overall Cronbach's Alpha value at 0.8779 indicates a fairly good internal consistency. None of the risk items received an average score of over 3.000, meaning that no risks were identified as likely to occur. The highest ranked risk item in Table 3 is DR2 related to the design experience of designers in OSC, indicating that survey respondents perceived lack of design experience for OSC projects the most frequently occurring issues. This was consistent with findings from previous studies (e.g., Yunus and Yang, 2014; Luo et al., 2017) that designer readiness for OSC was one of the 
main critical factors to implement OSC. The second highest ranked risk item according to RII values calculated in Table 3 is DR5 (i.e., insufficient design code for joints between prefabricated components). It has been emphasized and evaluated in multiple studies (e.g., Kim et al., 2017; Lee et al., 2017; Park et al., 2017) of the connection joints between modular members. In contrast, the two general risk items (i.e., GR1 and GR2) were perceived as least likely to occur among the 14 risk items. It is found from Table 3 that design related risks were identified by survey participants as more likely to occur compared to risks in construction, people and organization, or the general category.

The risk item DR2, together with DR1 (i.e., design insufficiently incorporating the local condition) and GR1 (i.e., insufficiently developed regulations and policies), received higher individual Cronbach's Alpha values than the overall value. Therefore, it was suggested that survey participants tended to have varied views towards DR1, DR2, and GR1, as they would normally do to other risk items. Survey participants' varied views on these three risk items is also evidenced by the corresponding lower Item-total Correlation. Table 4 and Table 5 provides the subgroup analysis of survey participants' perceptions towards the probabilities of risk items.

Table 4. Statistical comparison of subgroup perceptions towards the probability of risks involved in OSC (subgroups divided according to survey participants' experience in OSC)

\begin{tabular}{|l|c|c|c|c|c|c|c|}
\hline \multirow{2}{*}{$\begin{array}{l}\text { Risk } \\
\text { item }\end{array}$} & \multicolumn{4}{|c|}{ Subgroup mean value } & \multicolumn{2}{c|}{ ANOVA } & \multirow{2}{*}{ Post-hoc analysis } \\
\cline { 2 - 6 } & EOSC1 & EOSC2 & EOSC3 & EOSC4 & $\boldsymbol{F}$ value & $\boldsymbol{p}$ value & \\
\hline GR1 & 1.273 & 1.811 & 1.846 & 2.120 & $\mathbf{3 . 0 4}$ & $\mathbf{0 . 0 3 2}^{\mathbf{a}}$ & $\begin{array}{c}\text { EOSC4 and EOSC1 held significantly } \\
\text { different views }\end{array}$ \\
\hline GR2 & 1.545 & 1.811 & 1.564 & 2.240 & $\mathbf{4 . 9 2}$ & $\mathbf{0 . 0 0 3}^{\mathbf{a}}$ & $\begin{array}{c}\text { EOSC4 held significantly different } \\
\text { views with the other three subgroups }\end{array}$ \\
\hline DR1 & 2.636 & 2.486 & 2.359 & 2.600 & 0.71 & 0.547 & No significant differences \\
\hline DR2 & 3.182 & 3.027 & 2.897 & 3.000 & 0.32 & 0.809 & No significant differences \\
\hline DR3 & 2.364 & 2.595 & 2.641 & 2.680 & 0.56 & 0.644 & No significant differences \\
\hline DR4 & 2.455 & 2.459 & 2.513 & 2.920 & 2.29 & 0.083 & EOSC4 held somewhat different \\
\hline
\end{tabular}




\begin{tabular}{|l|c|c|c|c|c|c|c|}
\hline & & & & & & & views with EOSC1 and EOSC2 \\
\hline DR5 & 2.727 & 2.514 & 2.564 & 2.840 & 1.20 & 0.314 & No significant differences \\
\hline CR1 & 2.636 & 2.486 & 2.538 & 2.880 & 1.66 & 0.179 & $\begin{array}{c}\text { EOSC4 held somewhat different } \\
\text { views with EOSC2 }\end{array}$ \\
\hline CR2 & 2.818 & 2.595 & 2.590 & 2.560 & 0.28 & 0.839 & No significant differences \\
\hline CR3 & 2.636 & 2.351 & 2.564 & 2.280 & 0.62 & 0.604 & No significant differences \\
\hline POR1 & 2.545 & 2.568 & 2.410 & 2.640 & 0.60 & 0.617 & No significant differences \\
\hline POR2 & 2.545 & 2.568 & 2.308 & 2.560 & 1.18 & 0.322 & No significant differences \\
\hline POR3 & 2.545 & 2.541 & 2.359 & 2.800 & 2.02 & 0.116 & $\begin{array}{c}\text { EOSC4 held somewhat different } \\
\text { views with EOSC3 }\end{array}$ \\
\hline POR4 $^{2.364}$ & 2.595 & 2.436 & 2.720 & 1.26 & 0.292 & No significant differences \\
\hline Ave. & 2.448 & 2.458 & 2.399 & 2.631 & 1.25 & 0.295 & No significant differences \\
\hline
\end{tabular}

a: A $p$ value lower than 0.05 indicates significantly different perceptions among subgroups towards the given risk item. The same rule applies to the ANOVA results in follow-up tables.

${ }^{\mathrm{b}}$ : Ave. in the last row of Table 4 measures the average Likert-scale value of the 14 risk items for each survey respondent.

It can be found from Table 4 that two of the risk items (i.e., GR1 and GR2) received significantly different views from subgroups divided by different levels of experience in OSC projects. Especially for risk item GR1, those with higher level of OSC experience would perceive a lower probability of occurrence. Although most risk items received generally consistent views among subgroups of survey participants based on ANOVA, the post-hoc analysis further identified pairs of subgroups that held more different perceptions. For example, those with little OSC experience perceived the insufficient design code for modular components with higher chance of occurrence, compared to those with practical experience or knowledge in OSC. Fig.5 showcases the pair-based comparisons for GR1. 


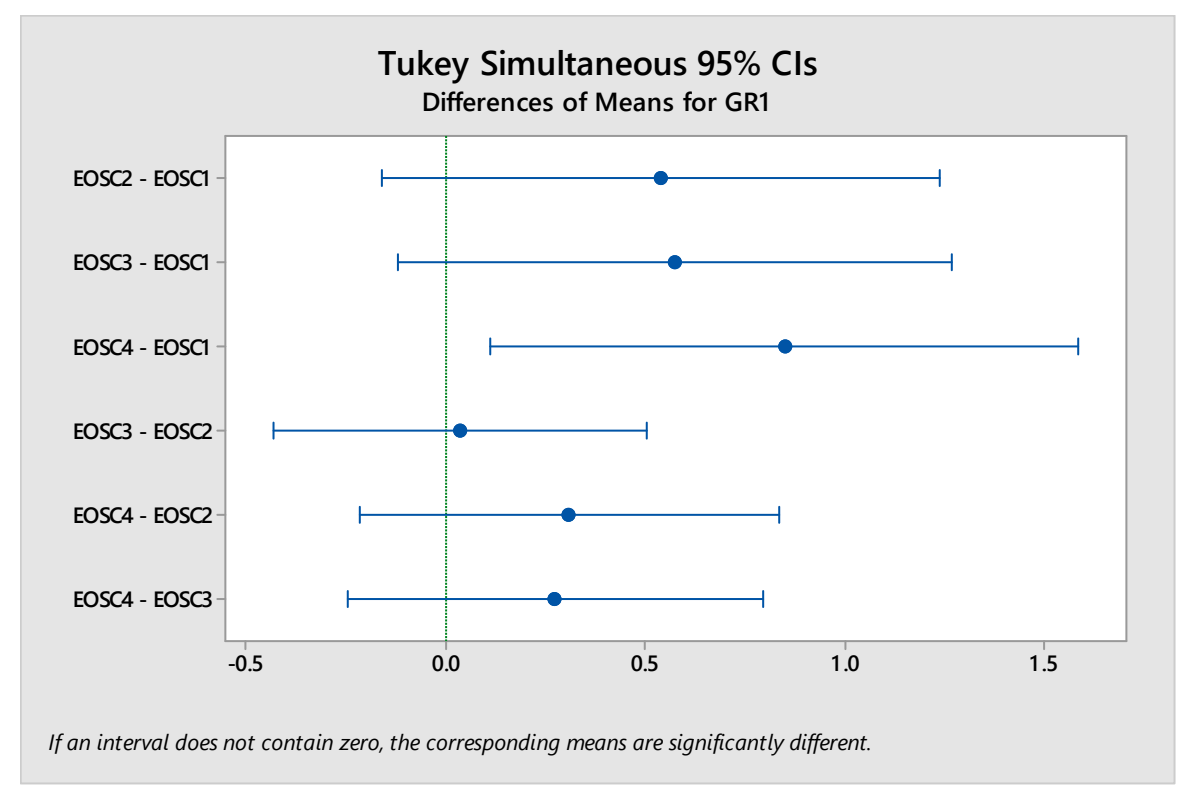

Fig.5. Pair-based comparisons between subgroups through post-hoc analysis for risk item GR1

Fig.5 demonstrates an example of how the significantly different perceptions between pairs of subgroups were identified through post-hoc analysis. For the risk item GR1 related to law, policy, and regulation, subgroup of EOSC4 (i.e., those with little OSC experience) tended to perceive it with a significantly higher probability of occurrence compared to those with sufficient practical OSC experience.

Table 5. Statistical comparison of subgroup perceptions towards the probability of risks involved in OSC (subgroups divided according to survey participants' experience in IDC)

\begin{tabular}{|l|c|c|c|c|c|c|c|}
\hline \multirow{2}{*}{$\begin{array}{c}\text { Risk } \\
\text { item }\end{array}$} & \multicolumn{4}{|c|}{ Subgroup mean value } & \multicolumn{2}{c|}{ ANOVA } & \multirow{2}{*}{ Post-hoc analysis } \\
\hline GR1 & 1.632 & 1.714 & 1.900 & 2.190 & 2.25 & 0.087 & $\begin{array}{c}\text { EIDC4 held somewhat different views } \\
\text { with EIDC1 and EIDC2. }\end{array}$ \\
\hline GR2 & 1.632 & 1.691 & 1.700 & 2.286 & $\mathbf{3 . 9 1}$ & $\mathbf{0 . 0 1 1}$ & $\begin{array}{c}\text { EIDC4 held significantly different } \\
\text { views with the other three subgroups. }\end{array}$ \\
\hline DR1 & 2.474 & 2.595 & 2.267 & 2.571 & 1.26 & 0.291 & No significant differences \\
\hline DR2 & 2.947 & 3.000 & 3.000 & 3.000 & 0.02 & 0.997 & No significant differences \\
\hline DR3 & 2.632 & 2.524 & 2.533 & 2.857 & 1.21 & 0.310 & No significant differences \\
\hline DR4 & 2.368 & 2.524 & 2.500 & 3.000 & $\mathbf{3 . 0 1}$ & $\mathbf{0 . 0 3 3}$ & $\begin{array}{c}\text { EIDC4 held significantly different } \\
\text { views with the other three subgroups. }\end{array}$ \\
\hline DR5 & 2.368 & 2.738 & 2.467 & 2.857 & 2.42 & 0.070 & $\begin{array}{c}\text { EIDC4 held somewhat different views } \\
\text { with EIDC1. }\end{array}$ \\
\hline
\end{tabular}




\begin{tabular}{|l|c|c|c|c|c|c|c|}
\hline CR1 & 2.368 & 2.476 & 2.633 & 3.048 & $\mathbf{4 . 0 2}$ & $\mathbf{0 . 0 0 9}$ & $\begin{array}{c}\text { EIDC4 held significantly different } \\
\text { views with the other three subgroups. }\end{array}$ \\
\hline CR2 & 2.421 & 2.643 & 2.600 & 2.714 & 0.48 & 0.698 & No significant differences \\
\hline CR3 & 2.526 & 2.524 & 2.300 & 2.381 & 0.35 & 0.793 & No significant differences \\
\hline POR1 & 2.368 & 2.548 & 2.533 & 2.619 & 0.44 & 0.725 & No significant differences \\
\hline POR2 & 2.316 & 2.548 & 2.433 & 2.524 & 0.57 & 0.638 & No significant differences \\
\hline POR3 & 2.474 & 2.452 & 2.500 & 2.810 & 1.32 & 0.271 & No significant differences \\
\hline POR4 & 2.474 & 2.500 & 2.467 & 2.810 & 1.38 & 0.253 & No significant differences \\
\hline Ave. & 2.357 & 2.463 & 2.417 & 2.690 & 2.01 & 0.117 & $\begin{array}{c}\text { EIDC4 held somewhat different views } \\
\text { with EIDC1 and EIDC3. }\end{array}$ \\
\hline
\end{tabular}

Those subgroups (i.e., GR2, DR4, and CR1) found with $p$ values lower than 0.05 indicated significantly different perceptions towards the given risk item as seen in Table 5. Other risk items (e.g., DR5 related to joint design for connecting off-site components), although with $p$ values over 0.05 suggesting insignificant overall subgroup differences, could still be identified with different perceptions between a pair of subgroups. Fig. 6 displays the post-hoc analysis identifying the significantly different perceptions between EIDC4 and EIDC1.

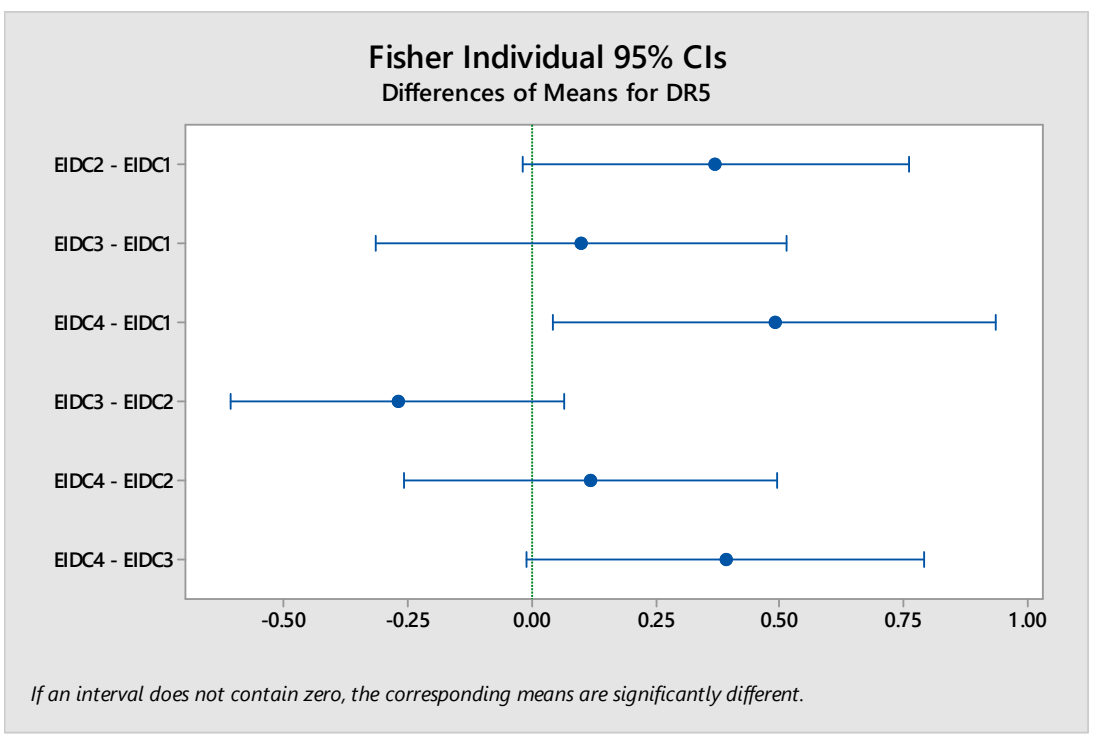

Fig.6. Pair-based comparisons between subgroups through post-hoc analysis for risk item DR5

It is indicated from Table 5 and Fig.6 that those with little IDC experience perceived a significantly higher probability of occurrence of risk item DR5 compared 
to those with most experience in IDC. Subgroup analysis reveals that there were more variations of perceptions towards risk probability among subgroups divided according to IDC experience compared to subgroups by OSC experience. The average perception analysis in Table 5 suggests that EIDC4 held differed views than those with more IDC experience or knowledge. It is also fair to summarize that AEC professionals with either less OSC or IDC experience would be more likely to overestimate the probability of risk items involved in OSC projects.

\subsection{Severity of risks involved in implementing OSC in the IDC project delivery}

The second Likert-scale question focused on the severity of the 14 defined risk items. Adopting the consistent statistical methods, the overall sample analysis is summarized in Table 6.

Table 6. Statistical analysis of survey participants towards the severity of risks involved in OSC in the IDC project delivery (overall Cronbach's Alpha value = $0.8952)$

\begin{tabular}{|l|c|c|c|c|c|c|}
\hline Risk item & $\begin{array}{c}\text { Item-total } \\
\text { Correlation }\end{array}$ & $\begin{array}{c}\text { Cronbach's } \\
\text { Alpha }\end{array}$ & Mean & $\begin{array}{c}\text { Standard } \\
\text { Deviation }\end{array}$ & $\boldsymbol{R} I \boldsymbol{R}$ & Ranking \\
\hline GR1 & 0.5278 & 0.8926 & 1.286 & 1.150 & 0.257 & 14 \\
\hline GR2 & 0.5506 & 0.8907 & 1.321 & 1.100 & 0.264 & 13 \\
\hline DR1 & 0.5729 & 0.8900 & 1.402 & 1.143 & 0.280 & 12 \\
\hline DR2 & 0.4660 & 0.8930 & 2.732 & 0.880 & 0.546 & 1 \\
\hline DR3 & 0.5245 & 0.8903 & 2.518 & 0.805 & 0.504 & 6 \\
\hline DR4 & 0.6257 & 0.8869 & 2.536 & 0.709 & 0.507 & 5 \\
\hline DR5 & 0.6271 & 0.8866 & 2.509 & 0.735 & 0.502 & 7 \\
\hline CR1 & 0.6175 & 0.8868 & 2.554 & 0.757 & 0.511 & 3 \\
\hline CR2 & 0.6816 & 0.8841 & 2.625 & 0.796 & 0.525 & 2 \\
\hline CR3 & 0.6358 & 0.8855 & 2.339 & 0.906 & 0.468 & 10 \\
\hline POR1 & 0.6216 & 0.8869 & 2.554 & 0.721 & 0.511 & 3 \\
\hline POR2 & 0.6627 & 0.8855 & 2.402 & 0.716 & 0.480 & 8 \\
\hline POR3 & 0.6087 & 0.8872 & 2.313 & 0.760 & 0.463 & 11 \\
\hline POR4 & 0.6296 & 0.8865 & 2.366 & 0.747 & 0.473 & 9 \\
\hline
\end{tabular}

The overall Cronbach's Alpha value at 0.8952 indicates a higher degree of internal consistency among survey respondents' perceptions towards the severity of the risk 
items. All individual Cronbach's Alpha values lower than the overall value mean that survey respondents held no significantly different views towards any individual risk items. Somewhat similar to the RII ranking of probability, the two general risk items (i.e., GR1 and GR2) are ranked the bottom in terms of their severity. The same risk item (i.e., DR2) was ranked highest in terms of both its probability and severity. But somewhat different from the measurement of risk probability in Table 3, other highly ranked risk items with higher severity fell more evenly into the categories among design, construction, and people and organization, including CR2 (i.e., safety and functions of temporary structures) and POR1 (i.e., experience and training of employees specifically for OSC projects). As the alternative to the conventional in-situ construction, Arashpour et al. (2018) emphasized the importance of skill transferability, training, and safety considerations in OSC. Fard et al. (2017) evaluated the safety performance for OSC projects involving the manufacturing and site construction activities and suggested that more research was needed on stabilizing stabilizing structures during their permanent installation as well as developing safety training programs for OSC. Further subgroup analyses were conducted and summarized in Table 7 and Table 8.

Table 7. Statistical comparison of subgroup perceptions towards the severity of risks involved in OSC (subgroups divided according to survey participants' experience in OSC)

\begin{tabular}{|l|c|c|c|c|c|c|c|}
\hline \multirow{2}{*}{$\begin{array}{l}\text { Risk } \\
\text { item }\end{array}$} & \multicolumn{4}{|c|}{ Subgroup mean value } & \multicolumn{2}{c|}{ ANOVA } & \multirow{2}{*}{ Post-hoc analysis } \\
\hline GR1 & 0.909 & 1.270 & 1.205 & 1.600 & 1.08 & 0.359 & No significant differences \\
\hline GR2 & 1.091 & 1.270 & 1.103 & 1.840 & 2.67 & 0.051 & $\begin{array}{c}\text { EOSC4 held somewhat different } \\
\text { views with EOSC2 and EOSC3. }\end{array}$ \\
\hline DR1 & 1.044 & 1.077 & 0.999 & 1.338 & $\mathbf{3 . 0 8}$ & $\mathbf{0 . 0 3 1}$ & $\begin{array}{c}\text { EOSC4 held significantly different } \\
\text { views with the other three subgroups. }\end{array}$ \\
\hline DR2 & 3.000 & 2.730 & 2.615 & 2.800 & 0.61 & 0.609 & No significant differences \\
\hline DR3 & 2.727 & 2.568 & 2.308 & 2.680 & 1.54 & 0.208 & No significant differences \\
\hline DR4 & 2.636 & 2.459 & 2.436 & 2.760 & 1.32 & 0.272 & No significant differences \\
\hline
\end{tabular}




\begin{tabular}{|l|c|c|c|c|c|c|c|}
\hline DR5 & 2.727 & 2.459 & 2.462 & 2.560 & 0.47 & 0.706 & No significant differences \\
\hline CR1 & 2.818 & 2.432 & 2.436 & 2.800 & 2.01 & 0.116 & No significant differences \\
\hline CR2 & 2.727 & 2.703 & 2.436 & 2.760 & 1.16 & 0.329 & No significant differences \\
\hline CR3 & 2.364 & 2.351 & 2.077 & 2.720 & $\mathbf{2 . 6 8}$ & $\mathbf{0 . 0 5 0}$ & $\begin{array}{c}\text { EOSC4 held significantly different } \\
\text { views with EOSC3. }\end{array}$ \\
\hline POR1 & 2.727 & 2.514 & 2.487 & 2.640 & 0.47 & 0.701 & No significant differences \\
\hline POR2 & 2.545 & 2.216 & 2.308 & 2.760 & $\mathbf{3 . 5 1}$ & $\mathbf{0 . 0 1 8}$ & $\begin{array}{c}\text { EOSC4 held significantly different } \\
\text { views with EOSC2 and EOSC3. }\end{array}$ \\
\hline POR3 & 2.364 & 2.351 & 2.179 & 2.440 & 0.68 & 0.568 & No significant differences \\
\hline POR4 & 2.545 & 2.243 & 2.308 & 2.560 & 1.19 & 0.317 & No significant differences \\
\hline Ave. & 2.292 & 2.205 & 2.117 & 2.491 & 2.44 & 0.068 & $\begin{array}{c}\text { EOSC4 held somewhat different } \\
\text { views with EOSC2 and EOSC3. }\end{array}$ \\
\hline
\end{tabular}

Several differences were found regarding subgroups' perceptions towards the severities of risk items, such as DR1 related to design incorporating local conditions, CR3 related to specifications for joint construction, and POR2 related to project execution risks. Unlike the subgroup perceptions towards the probability, no subgroups differences were found in the general risk category. Generally, those with little OSC experience also tended to perceive a higher risk level in light of the severity of risk items.

Table 8. Statistical comparison of subgroup perceptions towards the severity of risks involved in OSC (subgroups divided according to survey participants' experience in IDC)

\begin{tabular}{|c|c|c|c|c|c|c|c|}
\hline \multirow{2}{*}{\begin{tabular}{|l|} 
Risk \\
item
\end{tabular}} & \multicolumn{4}{|c|}{ Subgroup mean value } & \multicolumn{2}{|c|}{ ANOVA } & \multirow[t]{2}{*}{ Post-hoc analysis } \\
\hline & EIDC1 & EIDC2 & EIDC3 & EIDC4 & F value & $p$ value & \\
\hline GR1 & 0.579 & 1.238 & 1.300 & 2.000 & 5.78 & 0.001 & $\begin{array}{l}\text { EIDC4 held significantly different } \\
\text { views with the other three subgroups; } \\
\text { EIDC1 perceived with significantly } \\
\text { lower severity than other subgroups. }\end{array}$ \\
\hline$\overline{\text { GR2 }}$ & 0.895 & 1.167 & 1.200 & 2.190 & 6.58 & 0.000 & $\begin{array}{l}\text { EIDC4 held significantly different } \\
\text { views with the other three subgroups. }\end{array}$ \\
\hline$\overline{\mathrm{DR} 1}$ & 0.789 & 1.333 & 1.300 & 2.238 & 6.55 & 0.000 & $\begin{array}{l}\text { EIDC4 held significantly different } \\
\text { views with the other three subgroups. }\end{array}$ \\
\hline DR2 & 2.789 & 2.857 & 2.467 & 2.810 & 1.28 & 0.284 & No significant differences \\
\hline DR3 & 2.684 & 2.429 & 2.367 & 2.762 & 1.46 & 0.231 & No significant differences \\
\hline DR4 & 2.684 & 2.381 & 2.433 & 2.857 & 2.71 & 0.049 & $\begin{array}{l}\text { EIDC4 held significantly different } \\
\text { views with EIDC2 and EIDC3. }\end{array}$ \\
\hline$\overline{\text { DR5 }}$ & 2.579 & 2.548 & 2.367 & 2.571 & 0.51 & 0.673 & No significant differences \\
\hline$\overline{\mathrm{CR} 1}$ & 2.474 & 2.476 & 2.467 & 2.905 & 1.90 & 0.134 & $\begin{array}{l}\text { EIDC4 held significantly different } \\
\text { views with EIDC2 and EIDC3. }\end{array}$ \\
\hline
\end{tabular}




\begin{tabular}{|l|c|c|c|c|c|c|c|}
\hline CR2 & 2.684 & 2.548 & 2.500 & 2.905 & 1.29 & 0.282 & No significant differences \\
\hline CR3 & 2.316 & 2.310 & 2.033 & 2.857 & $\mathbf{3 . 7 0}$ & $\mathbf{0 . 0 1 4}$ & $\begin{array}{c}\text { EIDC4 held significantly different } \\
\text { views with EIDC2 and EIDC3. }\end{array}$ \\
\hline POR1 & 2.421 & 2.524 & 2.567 & 2.714 & 0.58 & 0.628 & No significant differences \\
\hline POR2 & 2.105 & 2.286 & 2.400 & 2.905 & $\mathbf{5 . 5 0}$ & $\mathbf{0 . 0 0 1}$ & $\begin{array}{c}\text { EIDC4 held significantly different } \\
\text { views with the other three subgroups. }\end{array}$ \\
\hline POR3 & 2.211 & 2.190 & 2.333 & 2.619 & 1.65 & 0.182 & $\begin{array}{c}\text { EIDC4 held somewhat different views } \\
\text { with EIDC2. }\end{array}$ \\
\hline POR4 & 2.368 & 2.214 & 2.367 & 2.667 & 1.74 & 0.162 & $\begin{array}{c}\text { EIDC4 held somewhat different views } \\
\text { with EIDC2. }\end{array}$ \\
\hline Ave. & 2.113 & 2.179 & 2.150 & 2.643 & $\mathbf{4 . 7 5}$ & $\mathbf{0 . 0 0 4}$ & $\begin{array}{c}\text { EIDC4 held significantly different } \\
\text { views with the other three subgroups. }\end{array}$ \\
\hline
\end{tabular}

More significant differences were found among subgroups divided according to their experience levels in IDC, including the average perception towards the 14 risk items. It is seen in Table 8 that EIDC4 (i.e., those with little IDC experience) held significantly more conservative views towards the severity of risks than three other subgroups who had more IDC experience. It was indicated that gaining the IDC experience would change the perception of AEC professionals from "the risk is severe if it occurs" to "the risk is less severe". Compared to the perception variation among subgroups from different OSC experience levels, more variations were caused by the different experience levels in IDC.

\subsection{Risk score of items involved in implementing OSC in the IDC project delivery}

The probability and severity of each risk item were integrated to evaluate the overall risk score as summarized in Table 9.

Table 9. Statistical analysis of risk scores involved in OSC in the IDC project delivery (overall Cronbach's Alpha value $=0.9103$ )

\begin{tabular}{|l|c|c|c|c|c|c|}
\hline Risk item & $\begin{array}{c}\text { Item-total } \\
\text { Correlation }\end{array}$ & $\begin{array}{c}\text { Cronbach's } \\
\text { Alpha }\end{array}$ & Mean & $\begin{array}{c}\text { Standard } \\
\text { Deviation }\end{array}$ & $\boldsymbol{R I I}$ & Ranking \\
\hline GR1 & $\mathbf{0 . 4 8 2 0}$ & $\mathbf{0 . 9 1 2 7}$ & 1.309 & 1.062 & 0.262 & 14 \\
\hline GR2 & 0.5355 & 0.9090 & 1.331 & 0.994 & 0.266 & 13 \\
\hline DR1 & $\mathbf{0 . 4 9 8 8}$ & $\mathbf{0 . 9 1 2 7}$ & 1.542 & 1.102 & 0.308 & 12 \\
\hline DR2 & 0.5176 & 0.9077 & 2.785 & 0.761 & 0.557 & 1 \\
\hline DR3 & 0.6188 & 0.9041 & 2.485 & 0.701 & 0.497 & 6 \\
\hline DR4 & 0.7252 & 0.9010 & 2.506 & 0.647 & 0.501 & 5 \\
\hline
\end{tabular}




\begin{tabular}{|l|c|c|c|c|c|c|}
\hline DR5 & 0.7193 & 0.9011 & 2.519 & 0.660 & 0.504 & 4 \\
\hline CR1 & 0.7207 & 0.9011 & 2.524 & 0.648 & 0.505 & 3 \\
\hline CR2 & 0.7367 & 0.8999 & 2.564 & 0.716 & 0.513 & 2 \\
\hline CR3 & 0.7136 & 0.9001 & 2.273 & 0.886 & 0.455 & 11 \\
\hline POR1 & 0.7165 & 0.9015 & 2.477 & 0.627 & 0.495 & 7 \\
\hline POR2 & 0.7228 & 0.9015 & 2.380 & 0.612 & 0.476 & 9 \\
\hline POR3 & 0.6565 & 0.9032 & 2.364 & 0.652 & 0.473 & 10 \\
\hline POR4 & 0.7237 & 0.9018 & 2.394 & 0.587 & 0.479 & 8 \\
\hline
\end{tabular}

It is seen in Table 9 that although there is a high degree of internal consistency among risk items, two of them (i.e., GR1 and DR1) received differed views from survey respondents. These two risk items related to the relevant policy/regulation, and design incorporating local conditions were considered with lowest risk scores by the overall survey population. The top three ranked items measured by risk scores were: DR 2(i.e., design experience of architects and engineers), CR2 (i.e., safety and function of temporary structures on-site), and CR1 (i.e., site storage and security for off-site manufactured components). In contrast, risks in the general category as well as people and organization did not receive highest rankings in terms of their risk scores. Subgroup analyses according to survey respondents' experience levels in OSC and IDC were conducted as seen in Table 10 and Table 11.

Table 10. Statistical comparison of risk scores involved in OSC (subgroups divided according to survey participants' experience in OSC)

\begin{tabular}{|l|c|c|c|c|c|c|c|}
\hline \multirow{2}{*}{$\begin{array}{l}\text { Risk } \\
\text { item }\end{array}$} & \multicolumn{3}{|c|}{ Subgroup mean value } & \multicolumn{2}{c|}{ ANOVA } & \multirow{2}{*}{ Post-hoc analysis } \\
\hline ER1 & EOSC1 & EOSC2 & EOSC3 & EOSC4 & F value & $\boldsymbol{p}$ value & \\
\hline GR2 & 0.715 & 1.310 & 1.269 & 1.630 & 1.98 & 0.121 & $\begin{array}{c}\text { EOSC4 held somewhat different } \\
\text { views with EOSC1 }\end{array}$ \\
\hline DR1 & 1.001 & 1.339 & 1.058 & 1.889 & $\mathbf{4 . 3 8}$ & $\mathbf{0 . 0 0 6}$ & $\begin{array}{c}\text { EOSC4 held significantly different } \\
\text { views with the other three subgroups }\end{array}$ \\
\hline DR2 & 1.133 & 1.455 & 1.463 & 1.975 & 1.99 & 0.119 & $\begin{array}{c}\text { EOSC4 held somewhat different } \\
\text { views with EOSC1 }\end{array}$ \\
\hline DR3 & 2.477 & 2.775 & 2.682 & 2.844 & 0.72 & 0.540 & No significant differences \\
\hline DR4 & 2.525 & 2.372 & 2.429 & 2.817 & $\mathbf{2 . 7 6}$ & $\mathbf{0 . 0 4 6}$ & $\begin{array}{c}\text { EOSC4 held significantly different } \\
\text { views with EOSC2 and EOSC3 }\end{array}$ \\
\hline DR5 & 2.701 & 2.406 & 2.473 & 2.679 & 1.20 & 0.313 & No significant differences \\
\hline
\end{tabular}




\begin{tabular}{|l|c|c|c|c|c|c|c|}
\hline CR1 & 2.701 & 2.352 & 2.454 & 2.809 & $\mathbf{3 . 0 8}$ & $\mathbf{0 . 0 3 1}$ & $\begin{array}{c}\text { EOSC4 held significantly different } \\
\text { views with EOSC2 and EOSC3 }\end{array}$ \\
\hline CR2 & 2.710 & 2.560 & 2.483 & 2.630 & 0.38 & 0.766 & No significant differences \\
\hline CR3 & 2.382 & 2.227 & 2.226 & 2.368 & 0.22 & 0.885 & No significant differences \\
\hline POR1 & 2.602 & 2.432 & 2.411 & 2.594 & 0.64 & 0.591 & No significant differences \\
\hline POR2 & 2.509 & 2.292 & 2.269 & 2.626 & 2.27 & 0.085 & $\begin{array}{c}\text { EOSC4 held somewhat different } \\
\text { views with EOSC2 and EOSC3 }\end{array}$ \\
\hline POR3 & 2.436 & 2.352 & 2.226 & 2.564 & 1.44 & 0.236 & $\begin{array}{c}\text { EOSC4 held somewhat different } \\
\text { views with EOSC3 }\end{array}$ \\
\hline POR4 & 2.405 & 2.323 & 2.332 & 2.591 & 1.27 & 0.287 & No significant differences \\
\hline Ave. & 2.239 & 2.191 & 2.155 & 2.476 & 2.16 & 0.097 & $\begin{array}{c}\text { EOSC4 held significantly different } \\
\text { views with EOSC2 and EOSC3 }\end{array}$ \\
\hline
\end{tabular}

Three risk items (i.e., GR2, DR4, and CR1) were found with significant risk scores among subgroups from different OSC experience levels. Overall, the average score indicated that those with little OSC experience were more likely to perceive a higher risk score compared to those with more experience or knowledge.

Table 11. Statistical comparison of subgroup risk scores involved in OSC (subgroups divided according to survey participants' experience in IDC)

\begin{tabular}{|c|c|c|c|c|c|c|c|}
\hline \multirow{2}{*}{\begin{tabular}{|l|} 
Risk \\
item
\end{tabular}} & \multicolumn{4}{|c|}{ Subgroup mean value } & \multicolumn{2}{|c|}{ ANOVA } & \multirow[t]{2}{*}{ Post-hoc analysis } \\
\hline & IDC1 & EIDC2 & EIDC3 & EIDC4 & F value & $p$ value & \\
\hline$\overline{\text { GR1 }}$ & 0.712 & 1.209 & 1.378 & 1.949 & 5.25 & 0.002 & $\begin{array}{c}\text { EIDC4 held significantly different } \\
\text { views with the other three subgroups; } \\
\text { EIDC1 perceived with significantly } \\
\text { lower severity compared to EIDC3 } \\
\text { and EIDC4. }\end{array}$ \\
\hline $\mathrm{R} 2$ & 91 & 1.132 & 1.243 & 2.161 & 7.33 & 0.000 & $\begin{array}{r}\text { EIDC4 held signifi } \\
\text { views with the other }\end{array}$ \\
\hline$\overline{\mathrm{DR} 1}$ & 1.066 & 1.491 & 1.453 & 2.202 & 4.11 & 0.008 & $\begin{array}{c}\text { EIDC4 held significantly different } \\
\text { views with the other three subgroups. }\end{array}$ \\
\hline $\mathrm{R} 2$ & 306 & 2.839 & 2.670 & 2.823 & & 0.816 & No significant differences \\
\hline DR3 & 19 & 2.378 & 2.377 & 2.731 & 9 & 0.173 & No significant differences \\
\hline DR4 & 2.491 & 2.361 & 2.438 & 2.909 & 3.80 & 0.012 & $\begin{array}{r}\text { EIDC4 hel } \\
\text { views with } \mathrm{t}\end{array}$ \\
\hline DR5 & 2.432 & 2.570 & 2.378 & 2.697 & & 326 & No significant diff \\
\hline CR1 & 2.364 & 2.392 & 2.509 & 2.953 & 11 & 0.006 & $\begin{array}{l}\text { EIDC4 held signifi } \\
\text { views with the other }\end{array}$ \\
\hline CR2 & 512 & 2.507 & 521 & 2.785 & 2 & 0.484 & No significant differences \\
\hline CR3 & 2.267 & 2.328 & 2.059 & 2.476 & 01 & 0.392 & No significant differences \\
\hline POR1 & 2.357 & 2.460 & 2.473 & 2.627 & 0.64 & 0.592 & No significant differences \\
\hline POR2 & 2.152 & 2.329 & 2.388 & 2.677 & 76 & 0.046 & $\begin{array}{l}\text { EIDC4 held significantly different } \\
\text { views with EIDC1 and EIDC2. }\end{array}$ \\
\hline POR3 & 2.302 & 2.227 & 388 & 2.658 & 17 & 0.095 & $\begin{array}{c}\text { EIDC4 held somewhat different views } \\
\text { with EIDC2. }\end{array}$ \\
\hline
\end{tabular}




\begin{tabular}{|c|c|c|c|c|c|c|c|}
\hline POR4 & 2.350 & 2.280 & 2.371 & 2.692 & 2.48 & 0.065 & $\begin{array}{c}\text { EIDC4 held somewhat different views } \\
\text { with EIDC2. }\end{array}$ \\
\hline Ave. & 2.101 & 2.179 & 2.189 & 2.596 & $\mathbf{4 . 2 0}$ & $\mathbf{0 . 0 0 7}$ & $\begin{array}{c}\text { EIDC4 held significantly different } \\
\text { views with the other three subgroups. }\end{array}$ \\
\hline
\end{tabular}

It is found from Table 11 that the level of experience in IDC significantly affected survey participants' risk perceptions. Overall, those with little IDC experience or knowledge held significantly different risk perceptions compared to three other subgroups with more experienced in IDC. Those with little IDC experience tended to perceive risks with a higher level of significance. Those most experienced in IDC (i.e., EIDC1), instead, might perceive risks (e.g., GR1 displayed in Fig.7) less significant compared to their counterparts with less IDC experience.

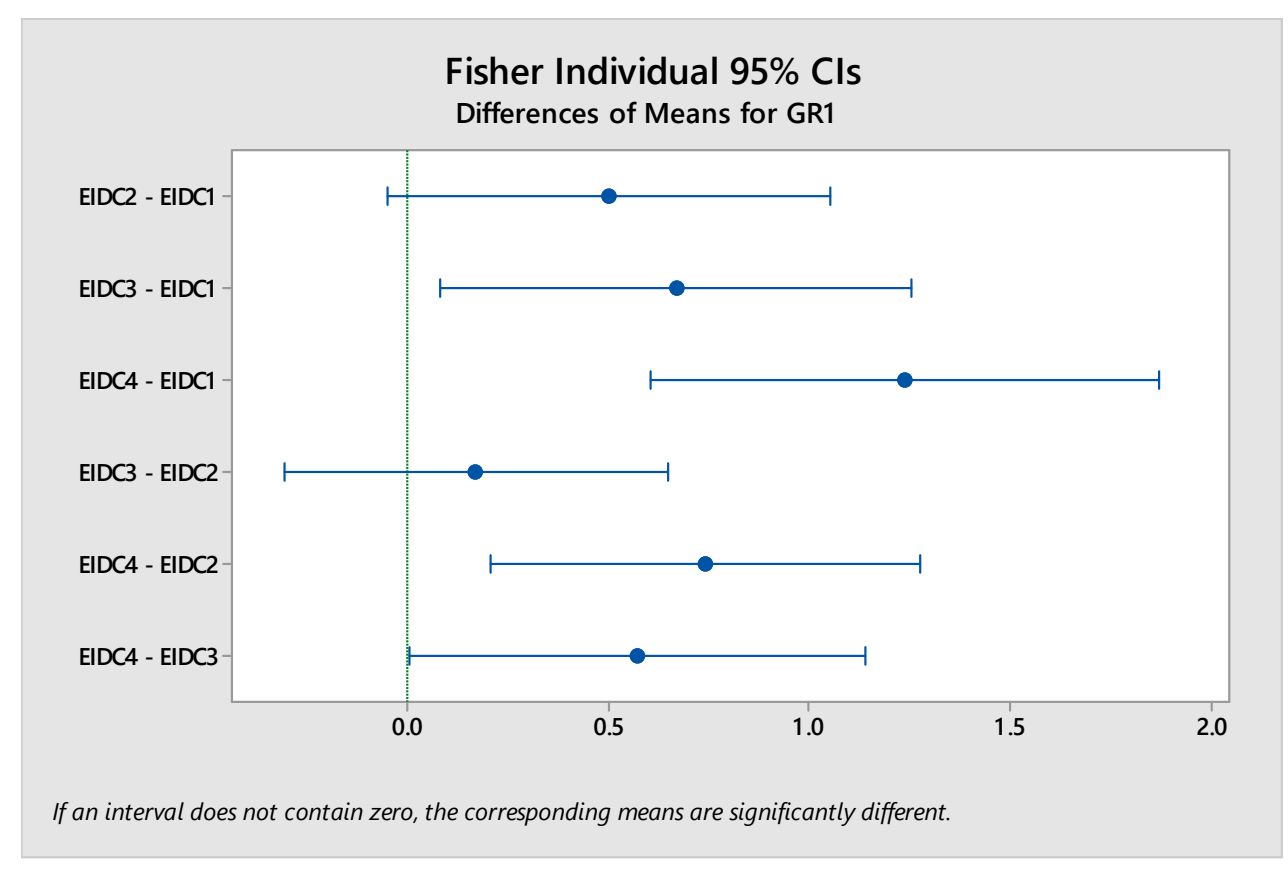

Fig.7. Post-hoc analysis of perceptions towards GR1 among subgroups divided according to IDC experience levels

The subgroup analyses of risk scores suggested that gaining more IDC experience would affect AEC professionals' risk perceptions in practicing OSC. Those with more IDC experience were more likely to perceive risks with a lower degree of significance. 


\section{Discussion}

Based on the 14 defined risk items involved in implementing OSC projects in the context of IDC project delivery approach, the questionnaire survey focusing on China's AEC professionals was designed and delivered aiming to the collect the perceptions of risk probability, severity, and risk score. The multiple choice-question showed that survey participants held varied views of whether OSC should be more widely applied in China's building industry, as well as how applying IDC approach in OSC would affect project risks. The further statistical analysis focused on the overall sample analysis and the investigations of perception variations among subgroups divided according to their experience levels in OSC and IDC. The statistical findings are illustrated in Fig.8.
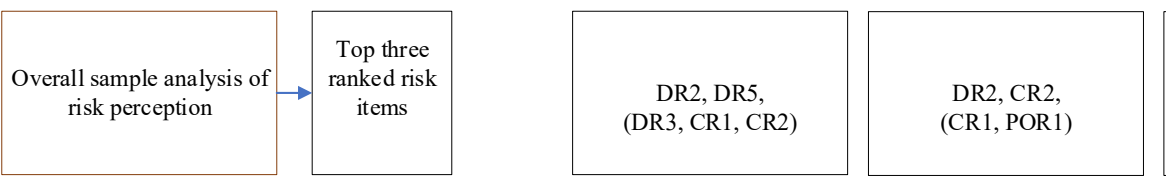

$\mathrm{DR} 2, \mathrm{CR} 2, \mathrm{CR} 1$
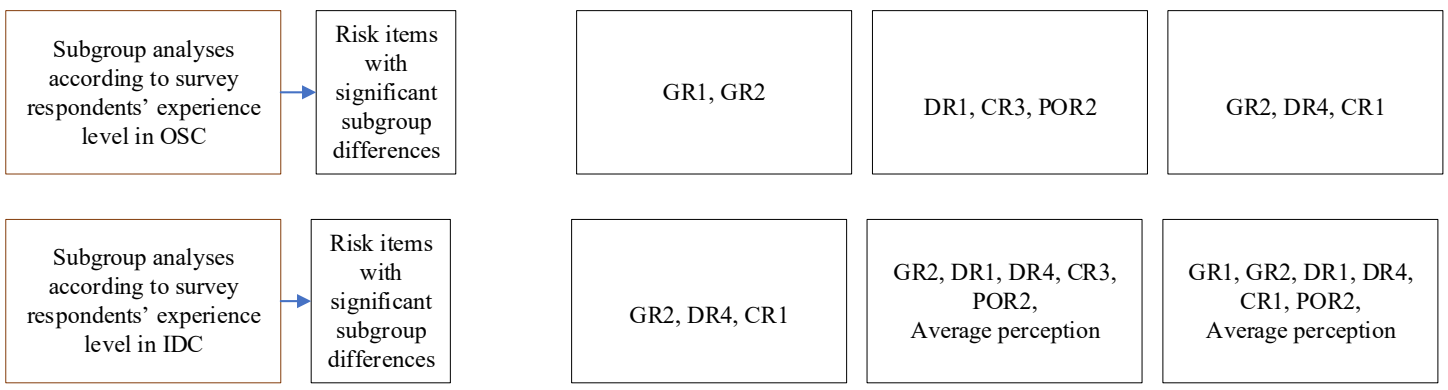

$$
\begin{gathered}
\text { GR1, GR2, DR1, DR4, } \\
\text { CR1, POR2, } \\
\text { Average perception }
\end{gathered}
$$

Note: DR3, CR1, and CR2 all ranked third in risk probability as they had the same RII value. The same case happened to CR1 and POR1 in risk severity measurement.

Fig.8. Summary of the statistical results in risk perception analysis

Most top ranked risk items in all the three measurements of risk items fell into the category related to design and construction. The design experience of architects and engineers was considered the most critical factor in implementing OSC in terms of all 
the three measurements. Other critical risk items identified included site safety, storage of modular components, and experience of employees in OSC. In contrast, general risk items as well as those in the category of people and organization defined in Table 1 were generally not ranked as high. According to existing studies (e.g., Jiang et al., 2015; Pozin et al., 2017), coordination and communication among OSC project team members and their OSC experience were critical for successful OSC implementation. The disparity between the survey findings in this study and existing studies regarding people and organization related risks could be due to the fact that most Chinese practitioners were more concerned about a single project stage (e.g., design) as they would mostly face in the traditional building project delivery. Less attention had been paid by them on viewing OSC as an integrated project approach with multiple stakeholders involved.

Although the overall survey population emphasized more on the design and construction related risks, variations of perceptions in the general risk category as well as the category related to people and organization due to different experience levels in OSC or in IDC were found through subgroup analyses. Fig.8 shows that experience in both OSC and IDC would affect AEC professionals' perceptions towards the risk items in implementing OSC in terms of probability, severity, and risk score. More significant variations were found among subgroups divided according to IDC experience levels, compared to those divided by OSC experience levels. Also, more variations were found in the risk measurement in terms of severity compared to probability. Consistent among risk probability, severity, and risk score, those with little OSC or IDC experience were more likely to perceive risk items with higher degrees of significance. But less significant differences were found between those 
having certain relevant knowledge but limited practice and those with sufficient practical experience.

Proper training or exposure of employees to OSC techniques and IDC project delivery approach would influence their risk perceptions in OSC projects. Due to the rare practices of implementing OSC adopting the IDC approach, this study was limited to the risk perception measurements. Continued from this research, more empirical case studies from China's construction industry are necessary in the future to test the risk perceptions. This study could be integrated with prior studies in the field of construction project management to further advance the body of knowledge, for example:

- extending the study of reverse logistics, which was introduced by Rameezdeen et al. (2015) to the construction sector, to OSC in a IDC project delivery system;

- similar to the study of Hosseini et al. (2018a) in the construction sector, the questionnaire survey sample was limited to a single country. Future research could target on international comparison of risk perceptions towards implementing OSC in IDC delivery method among countries such as China (Hong et al., 2018) and Australia (Mostafa et al., 2015);

- the effects of OSC on the tendering and bidding practices as described by Shokri-Ghasabeh and Chileshe (2016) compared to the conventional construction technique, especially in the IDC delivery approach;

- comparison of critical success factors for risk assessment and management (Chileshe and Kikwasi, 2014) between OSC and conventional construction techniques;

- application of BIM in OSC within the IDC delivery approach as suggested by Hosseini et al. (2018b). 


\section{Conclusion}

Despite of the fact that integrated design \& construction (IDC) could be closely integrated into off-site construction (OSC) techniques, there have been insufficient studies addressing the issues of implementing OSC in an IDC approach. Although implementing OSC in the IDC delivery approach has started being emphasized in China's construction industry, there has been so far limited research addressing the risks related to the adoption of OSC in IDC approach. This research aimed to investigate the risk perceptions of Professionals in China adopting OSC in the context of IDC. A total of 14 key risk items were pre-defined through the literature review followed by expert review. A follow-up questionnaire was designed targeting on industry professionals from different experience levels of OSC and IDC. A total of 112 valid responses were received from multiple professional organizations in China's architectural, engineering, and construction industry. Survey responses were analyzed in a comprehensive statistical approach, including the overall risk perception analysis and subgroup analysis to survey participants from different experience levels of OSC and IDC.

The overall sample analysis revealed that survey participants held varied visions of the OSC projects in China's building sector, as well as differed opinions on how applying IDC in OSC would affect project risks. The design experience of architects and engineers for OSC was considered the most critical risk factor as measured in terms of both risk probability and severity. Design and construction related risks (e.g., connection joint) were considered more significant factors compared to the general risks (e.g., policy and regulation) and people and organization-related risks (e.g., project coordination). 
The subgroup analysis indicated that AEC professionals' experience or knowledge in IDC approach and in OSC projects would affect their perceptions towards potential risks involved in implementing OSC. It was further identified that the subgroup variations of risk perceptions were generated more from the risk severity than probability. Those with less experience or knowledge in OSC projects would be more likely to perceive higher degrees of probability and severity of risks involved in OSC. Similar findings were identified in subgroups divided by IDC experience levels, as those with less IDC experience also tended to perceive risk items with higher degrees of probability and severity. Compared to the experience in OSC, the experience in IDC project delivery was found more significantly affecting practitioners' perceptions towards the risks involved in OSC projects adopting IDC approach. Overall, gaining more experience in either OSC or IDC would affect practitioners' risk perceptions of implementing OSC adopting IDC approach. Basically, those with more experience in OSC or IDC were more likely to perceive risk items with a lower degree of significance.

This research contributes to the body of knowledge of OSC implementation adopting the IDC approach. It serves as the prior work by linking IDC project delivery approach into OSC based on the fact that limited research or practical work has been conducted by applying IDC in OSC projects. Specifically, the current study addressed the question of what typical risks are when implementing OSC in a certain country context (e.g., China). Further, the research tested the hypotheses of whether stakeholders' perceptions would be affected by their experience in OSC and IDC. It was suggested that exposing AEC professionals to more IDC practice or providing IDC related training could cause a more significant mindset change towards OSC implementation. Proper training or exposure of employees to OSC techniques and 
IDC project delivery approach would influence their risk perceptions in OSC projects. It was indicated that gaining the IDC experience would change the perception of AEC professionals from "the risk is severe if it occurs" to "the risk is less severe".

This study is limited to the risk perceptions of industry practitioners towards implementing OSC in the IDC project delivery approach. The current study is limited to the AEC market in China. Future work could involve case studies or more empirical studies of risk management in OSC adopting IDC approach. The findings generated from this study could be extended to other developing and developed countries to allow international comparison of the implementation of OSC. The continued work could extend the study adopting IDC for OSC projects, by integrating it with other research topics in construction management, such as reverse logistics and Building Information Modeling.

\section{Acknowledgement}

The authors would like to acknowledge the support from Institutional Laboratory Research Project of Zhejiang Province (Contract No. 20180109) and the support from China Academy of Railway Sciences Corporation Ltd.

\section{References}

Akintoye, A. S., and MacLeod, M. J. (1997). "Risk analysis and management in construction." Int. J. Pro. Manage.15(1), 31-38.

Arashpour, M., Wakefield, R., Abbasi, B., Arashpour, M., and Hosseini, R. (2018). "Optimal process integration architectures in off-site construction: Theorizing the use of multi-skilled resources." Architectural Engineering and Design Management, 14, 46-59.

Bing, L., Akintoye, A., Edwards, P.J., and Hardcastle, C. (2005). "The allocation of risk in PPP/PFI construction projects in the UK." Int. J. Proj. Manage., 23(1), 25-35.

Bogus, S.M., Migliaccio, G.C., and Jin, R. (2013). "Study of the relationship between procurement duration and project performance in Design-Build Projects: comparison between water/wastewater and transportation Sectors." Journal of Management in Engineering, 29(4), 382-391.

Carifio, L., and Perla, R. (2008). "Resolving the 50 year debate around using and misusing Likert scales.” Med. Educ., 42(12), 1150-1152. 
Chan, A.P.C., Ho, D.C.K., and Tam, C.M. (2001). "Design and Build Project Success Factors: Multivariate Analysis." J. Constr. Eng. Manage., 127(2), 93-100.

Chang, F., and Fan, L. (2016). "Research on the design and manufacturing of prefabricated concrete components." Henan Building Materials. 3, 7-9. DOI:10.16053/j.cnki.hnjc.2016.03.003. (In Chinese)

Chileshe, N., Hosseini, M.R., and Jepson, J. (2016). "Critical barriers to implementing risk assessment and management practices (RAMP) in the Iranian construction sector." Journal of Construction in Developing Countries, 21(2), 81-112. https://dx.doi.org/10.21315/jcdc2016.21.2.5.

Chileshe, N., and Kikwasi, G.J. (2014a)." Critical success factors for implementation of risk assessment and management practices within the Tanzanian construction industry." Engineering, Construction and Architectural Management, 21(3), 291-319. DOI: 10.1108/ECAM-01-2013-0001.

Chileshe, N., and Kikwasi, G.J. (2014b). "Risk assessment and management practices (RAMP) within the Tanzania construction industry: Implementation barriers and advocated solutions." International Journal of Construction Management, DOI: 10.1080/15623599.2014.967927.

Chen, J. H., Yan, S., Tai, H.W. and Chang, C.Y. (2017). "Optimizing profit and logistics for precast concrete production." Canadian Journal of Civil Engineering, 44(6), 393-406.

Chiang, Y. H., Chan, E. H. W., and Lok, L. K. L. (2006). "Prefabrication and barriers to entry - a case study of public housing and institutional buildings in Hong Kong." Habitat Int. 30(3), 482-499.

China Construction News (2016). "Three key issues in the design of prefabricated construction." Available via http://www.chinajsb.cn/bz/content/2016-06/08/content 191024.htm, accessed on April $9^{\text {th }}, 2018$. (In Chinese)

Choi, J. O., Chen, X. B., and Kim, T. W. (2018). "Opportunities and challenges of modular methods in dense urban environment." International Journal of Construction Management, In Press.

Chu, H., Zhang, M., and Li, J. (2017). "Experiences summarization of the design for assembly house." Zhejiang Construction, 34(2). DOI:10.15874/j.cnki.cn33-1102/tu.2017.02.005. (In Chinese)

Cronbach, L. J. (1951). "Coefficient alpha and the internal structure of tests."Psychometrika., 16 (3), 297-334.

DeVellis, R. F. (2003). "Scale development: theory and applications."2nd Ed., SAGE Publications, Inc., Thousand Oaks, CA.

Ding, X., and Xu, F. (2018). "Bayesian Network Modeling for project risk management: a case study of Hong Kong-Zhuhai-Macao Bridge." Journal of Systems \& Management, 27 (1), 1005-2542, 01-0176-10.

Eadie, R., Browne, M., Odeyinka, H., McKeown, C., and McNiff, S., 2013. BIM implementation throughout the UK construction project lifecycle: An analysis. Autom. Constr., 36, 145-151.

Fard, M.M., Terouhid, S.A., Kibert, C.J., and Hakim, H. (2017). "Safety concerns related to modular/prefabricated building construction." International Journal of Injury Control and Safety Promotion, 24(1), 10-23.

Fernández, J.E. (2008). "Resource consumption of new urban construction in China." Journal of Industrial Ecology. 11(2), 99-115. 
Gan X., Chang R., and Wen T. (2018a)“Overcoming barriers to off-site construction through engaging stakeholders: A two-mode social network analysis." J. Clean. Prod. 201, 735-747.

Gan, X., Chang, R., Zuo, J., Wen, T., and Zliiante, G. (2018b). "Barriers to the transition towards off-site construction in China: an interpretive structural modeling approach." J. Clean. Prod. 197, 8-18.

Grosskopf, K. R., J. W. Elliott and J. E. Killingsworth (2017). "Offsite construction-U.S. market trends in prefabrication. Challenges for Technology Innovation: An Agenda for the Future." - Proceedings of the International Conference on Sustainable Smart Manufacturing, S2M 2016.

Guo, Z., and Zhang, R. (2017). "Research on safety risk management of prefabricated construction." Value Engineering, 35-36. DOI:10.14018/j.cnki.cn13-1085/n.2017.26.015. (In Chinese)

Hallikas, J., Karvonen, I., Pulkkinen, U., Virolainen, V. M., and Tuominen, M. (2004). "Risk management processes in supplier networks." International Journal of Production Economics. 90(1), 47-58.

Han, Y., Feng, Z., Zhang, J., Jin, R., and Aboagye-Nimo, E.(2019). "Employees' safety perceptions of site hazard and accident scenes." J. Constr. Eng. Manage., 145(1): 04018117. https://doi.org/10.1061/(ASCE)CO.1943-7862.0001590.

He, L. (2008). "Study on the evaluation of contractor's engineering risks under EPC model." Master Thesis. Tianjin University, Tianjin, China. 22-23, 28-32.

Hong, J., Shen, G.Q.P., Li, Z., Zhang, B., and Zhang, W. (2018). "Barriers to promoting prefabricated construction in China: A cost-benefit analysis." J. Clean. Prod.172: 649-660.

Hosseini, M.R., Banihashemi, S., Chileshe, N., Namzadi, M.O., Udaeja, C., Rameezdeen, R., and McCuen, T. (2016). "BIM adoption within Australian Small and Medium-sized Enterprises (SMEs): an innovation diffusion model." Construction Economics and Building, 16(3), 71-86.

Hosseini, M. R., Chileshe, N., Jepson, J., and Arashpour, M. (2016b). "Critical success factors for implementing risk management systems in developing countries." Construction Economics and Building, 16(1), 18-32. DOI: http://dx.doi.org/10.5130/AJCEB.v1i1.4651.

Hosseini, M.R., Martek, I., Chileshe, N., Zavadskas, E.K., and Arashpour, M. (2018a). "Assessing the Influence of Virtuality on the Effectiveness of Engineering Project Networks: "Big Five Theory" Perspective." J. Constr. Eng. Manage., 2018, 144(7): 04018059.

Hosseini, M.R., Martek, I., Zavadskas, E.K., Aibinu, A.A., Arashpour, M., and Chileshe, N. (2018b). "Critical evaluation of off-site construction research: a scientometric analysis." Autom. Constr., 87, 235-247.

Ismail Z.-A., MutalibA.A., and Hamzah N. (2016). "Case study to analyse problems and issues in IBS building maintenance."International Journal of Applied Engineering Research, 11(1), 226-232.

Ji, Y., Jiao, R. J., Chen L., and Wu, C. (2013). "Green modular design for material efficiency: A leader-follower joint optimization model." J. Clean. Prod. 41, 187-201.

Ji, Y., Zhu, F., Li H. X., and Al-Hussein, M. (2017). "Construction industrialization in China: Current profile and the prediction." Appl. Sci. (Switzerland),6, 180.

Jiang, L., Li, Z., Li, L., and Gao, Y. (2018a) "Constraints on the promotion of prefabricated construction in China." Sustainability, 10(7), 2516. DOI: $10.3390 /$ su10072516. 
Jiang, Q., Huang, Q., Chang, S., and Xu, Y. (2016). "Quality management and acceptance of the prefabricated concrete structure engineering." Quality Management. 34(4), 5-13.

Jiang, R., Mao, C., Hou, L., Wu, C., and Tan, J. (2018b). "A SWOT analysis for promoting off-site construction under the backdrop of China's new urbanisation." $J$. Clean. Prod. 173, 225-234.

Jiang, S., Zhang, Z., and Wang, J. (2015). "Construction management and quality control for precast concrete construction." Construction and Management. 67-71.

Jin, R. (2010). "Relationship between procurement duration and project performance in design-build water/wastewater projects." Master's thesis, University of New Mexico, Albuquerque, NM, U.S.

Jin, R., Gao, S., Cheshmehzangi, A., and Aboagye-Nimo,E. (2018). "A Holistic Review of off-site Construction Literature Published between 2008 and 2018." J. Clean. Prod., 202, 1202-1219. DOI: 10.1016/j.jclepro.2018.08.195.

Jin, R., Li, B., Zhou, T., Wanatowski, D., and Piroozfar, P. (2017). “An empirical study of perceptions towards construction and demolition waste recycling and reuse in China." Resources, Conservation and Recycling, 126, 86-98.

Kamar, K. A. M., Alshawi, M., and Hamid, Z. A. (2009). "Barriers to industrialised building system (IBS): the case of Malaysia." In M. Alshawi, V. Ahmed, C. Egbu, $\&$ M. Sutrisna (Eds.), BuHu 9th International postgraduate research conference (IPGRC). Salford, UK.

Kent, D., and Becerik-Gerber, B. (2010). "Understanding construction industry experience and attitudes toward integrated project delivery." J. Constr. Eng. Manage., 10.1061/(ASCE)CO.1943-7862.0000188, 815-825.

Kim, J., Hong, W.K., and Kim, J.H. (2017). "Experimental investigation of the influence of steel joints upon the flexural capacity of precast concrete columns."Structural Design of Tall and Special Buildings, 26(5), e1340.

Konchar, M., and Sanvido, V. (1998). "Comparison of U.S project delivery systems." J. Constr. Eng. Manage., 124(6), 435-444.

Kong, L., Li, H., Luo, H., Ding, L., Luo, X., and Skitmore, M. (2017). "Optimal single-machine batch scheduling for the manufacture, transportation and JIT assembly of precast construction with changeover costs within due dates." Automation in Construction, 81, 34-43.

Laerd Statistics (2018). "One-way ANOVA." Available via < https://statistics.laerd.com/statistical-guides/one-way-anova-statistical-guide-4.php >. Accessed on 6 November 2018.

Lee, S., Park, J., Kwak, E., Shon, S., Kang, C., and Choi, H. (2017). "Verification of the seismic performance of a rigidly connected modular system depending on the shape and size of the ceiling bracket." Materials, 10(3), 263.

Li, C.Z., Hong, J., Xue, Fan, Shen, G.Q., Xu, X. and Luo, L. (2016). "SWOT analysis and Internet of Things-enabled platform for prefabrication housing production in Hong Kong." Habitat International, 57, 74-87.

Li, Z., Shen, G.Q., and Xue, X. (2014). "Critical review of the research on the management of prefabricated construction." Habitat International, 43, 240-249.

Liao, L. (2018). "Experience analysis on the design, manufacture and construction of fabricated concrete structure." Fujian Construction Technology. 2, 59-62.

Ling, Y. Y. F., Chan, L. S., Chong, E., and Ee, P. L. (2004). "Predicting performance of design-build and design-bid-build projects." J. Constr. Eng. Manage., 130(1), $75-83$. 
Luo, L.Z., Mao, C., Shen, L.Y., and Li, Z.D. (2015). "Risk factors affecting practitioners' attitudes toward the implementation of an industrialized building system a case study from China."Engineering, Construction and Architectural Management, 22(6), 622-643.

Luo, J., Zhang, H., and Shen, W. (2017). "Insights into architects' future roles in off-site construction."Construction Economics and Building, 17(1), 107-120.

Ma, L., Le, Y., Li, H., Jin, R., Piroozfar, P., and Liu, M.(2018). "Regional comparisons of contemporary construction industry concepts in the Chinese Context." Sustainability. 10(11), 3831; DOI:10.3390/su10113831.https://www.mdpi.com/2071-1050/10/11/3831/htm.

Mao, C., Shen, L., Luo, L., and Li, Z. (2015). "Identification of Risk Factors Influencing the Implementation of Industrialized Building System in China." Proceedings of the 19th International Symposium on Advancement of Construction Management and Real Estate,(pp. 219-230). Springer, Berlin, Heidelberg.DOI: 10.1007/978-3-662-46994-1_19.

Mao, C., Shen, Q., Pan,W., and Ye, K. (2013). "Major barriers to off-site construction: the developer's perspective in China." Journal of Management in Engineering, 31(3), 04014043.

Mao, C., Xie, F., Hou, L., Wu, P., Wang, J., and Wang, X. (2016). "Cost analysis for sustainable off-site construction based on a multiple-case study in China." Habitat International, 57, 215-222.

Mesa, H. A., Molenaar, K. R., and Alarcón, L. F. (2016). "Exploring performance of the integrated project delivery process on complex building projects." Int. J. Proj. Manage., 34(7), 1089-1101.

Migliaccio, G. C., Gibson, G. E., and O’Connor, J. T. (2009). "Procurement of design-build services: Two-phase selection for highway projects." J. Manage. Eng., 25(1), 29-39.

Minghini, F., Ongaretto, E., Ligabue, V., Savoia, M., and Tullini, N. (2016). "Observational failure analysis of precast buildings after the 2012 Emilia earthquakes." Earthquake and Structures, 11(2), 327-346.

Mostafa, S., Abdelhamid, T, Chileshe, N., and. Dumrak, J. (2016). "Decision support model using ANP to align leagile strategies to off-site manufacturing in Australia." International Journal of the Analytic Hierarchy Process, 7(3), 374-404.

Mostafa, S., and Chileshe, N. (2018). "Application of discrete-event simulation to investigate effects of client order behaviour on off-site manufacturing performance in Australia." Architectural Engineering and Design Management, 14 (1-2), 139-157.

Mostafa, S., Chileshe, N., and Abdelhamid, T. (2016). "Lean and agile integration within offsite construction using discrete event simulation: A systematic literature review."Construction Innovation, 16 (4), 483-525.

Mostafa, S., Chileshe, N., and Zuo, J. (2014a). "A synergistic supply chain enhancing offsite manufacturing uptake in Australian house building." Procs $30^{\text {th }}$ Annual ARCOM Conference, Portsmouth, UK, Association of Researchers in Construction Management, 1143-1152.

Mostafa, S., Dumrak, J., Chileshe, N., and Zuo, J. (2014b). "Offsite manufacturing in developing countries: current situation and opportunities." International Conference on Engineering, Project, and Production Management. Port Elizabeth, South Africa. 64-73. 
$\mathrm{Mu}, \mathrm{Z}$. (2015). "Development Research of China's Construction Industry under the Background of the New Urbanization." Qingdao Technological University, Shandong (In Chinese).

Nawi, M. N. M., Lee, A., and Nor, K. M. (2011). "Barriers to implementation of the Industrialized Building System (IBS) in Malaysia." The Built \& Human Environment Review. 4, 22-35.

Nawi, M.N.M., Haron, A.T., Hamid, Z.A., Kamar, K.A.M., and Baharuddin, Y. (2014). "Improving integrated practice through Building Information Modeling-Integrated Project Delivery (BIM-IPD) for Malaysian Industrialised Building System (IBS) construction projects." Malaysian Construction Research Journal, 15(2): 29-38.

Norman, G. (2010). "Likert scales, levels of measurement and the 'laws' of statistics." Adv. Health. Sci. Edu., 15(5), 625-632.

Osman, W.N., Nawi, M.N., Anuar, H.S., Radzuan, K., and Osman, N.N. (2015). "Readiness assessment for implementation of Integrated Project Delivery (IPD) in Industrialised Building System (IBS) projects." JurnalTeknologi, 77(4), 91-95.

Park, J., Choi, J., Jang, Y., Park, S.K., and Hong, S. (2017). "An experimental and analytical study on the deflection behavior of precast concrete beams with joints." Applied Sciences (Switzerland), 7(11), 1198.

Pozin M.A.A., NawiM.N.M., AzmanM.N.A., and Lee A. (2017). "Improving communication in managing industrialised building system (IBS) projects: Virtual environment." Malaysian Construction Research Journal, 2, 1-13.

Rahman, M.M. "Barriers of implementing modern methods of construction."Journal of Management in Engineering, 30(1), 69-77.

Rameezdeen, R., Chileshe, N., Hosseini, M.R., and Lehmann, S. (2015). "A qualitative examination of major barriers in implementation of reverse logistics within the South Australian construction sector." International Journal of Construction Management, 16(3), 185-196, DOI: 10.1080/15623599.2015.1110275.

the South Australian construction sector

Sahin, O., Miller, D., and Mohamed, S. (2018). "Value-based modelling: an Australian case of off-site manufactured buildings." International Journal of Construction Management, 18(1), 34-52.

Shanghai Housing and Urban and Rural Construction Management Committee (2016). "The 2016-2020 Development Plan for Shanghai's Prefabricated Construction." Available via http://www.shjjw.gov.cn/Attach/Attaches/201701/201701170326311191.pdf (in Chinese), accessed on July $11^{\text {th }}, 2018$.

Shokri-Ghasabeh, M., and Chileshe, N. (2016). "Critical factors influencing the bid/no bid decision in the Australian construction industry." Construction Innovation, 16(2), 127-157. DOI 10.1108/CI-04-2015-0021.

Shrestha, P. P., Batista, J., and Maharjan, R. (2016). "Risks Involved in Using Alternative Project Delivery (APD) Methods in Water and Wastewater Projects." Procedia Engineering, 145, 219-223.

Slovic, P. (1992). "Perception of risk: Reflections on the psychometric paradigm." Decision Research. Eugene, Oregon, U.S.

Smits, W., Buiten, M.V., and Hartmann, T. (2017). "Yield-to-BIM: impacts of BIM maturity on project performance." Build. Res. Inf., 45(3), 336-346, DOI: 10.1080/09613218.2016.1190579. 
Statistics How To (2018). "Post-hoc definition and types of post hoc tests." Available via < https://www.statisticshowto.datasciencecentral.com/post-hoc/\#PHfishers>, accessed on 12 August 2018.

$\mathrm{Su}, \mathrm{Y}$., Zhao, J., and Xu, Y. (2016). "Research of quality defects about industrialized building in construction." Journal of Engineering Management, 30(4), 19-23. (In Chinese)

Swierk, E. (2005). "Prefabricated residential construction, project report for ARCH 030." available at: website http://www-cs-students.stanford.edu/weswierk/misc/arch030/prefab-report.pdf. Accessed on March 10 $0^{\text {th }}, 2018$.

Tam, V.W.Y. (2009). "Comparing the implementation of concrete recycling in the Australian and Japanese construction industries." J. Clean. Prod., 17(7), 688-702.

Tam, V.W.Y., Fung, I.W.H., Sing, M.C.P. and Ogunlana, S.O. (2015). "Best practice of prefabrication implementation in the Hong Kong public and private sectors." $J$. Clean. Prod., 109, 216-231.

Tam, V. W. Y., Tam, C. M., Zeng, S. X., and Ng, W. C. Y. (2007). "Towards adoption of prefabrication in construction." Build. Environ. 42(10), 3642-3654.

Tian, L. (2014). "Field Construction Technology and Safety Risk Management for Prefabricated Assembled Housing." Residential Technology. 06, 91-96.DOI:10.13626/j.cnki.hs.2014.06.023. (In Chinese)

The State Council (2016). "Several Opinions on Further Strengthening the Management of Urban Planning and Construction." The State Council, Beijing.

Vaghei, R., Hejazi, F., Taheri, H., Jaafar, M.S., and Ali, A.A.A. (2016). "A new precast wall connection subjected to monotonic loading."Computers and Concrete, $17(1), 1-27$.

Wang, A., Yang, Z., Wang, L., and Wang, S. (2015). "Organization and management of assembled monolithic concrete shear wall construction." Architecture Technology. 46(3), 224-227. DOI:10.13731/j.issn.1000-4726.2015.03.007. (In Chinese)

Wang, Q., Zeng, Y.E., and Wu, B.W. (2016). "Exploring the relationship between urbanization, energy consumption, and $\mathrm{CO} 2$ emissions in different provinces of China." Renew. Sustain. Energy Rev. 54, 1563-1579.

Wang T., Gao S., Li X., and Ning X. (2018). "A meta-network-based risk evaluation and control method for industrialized building construction projects." J. Clean. Prod. 205, 552-564.

Xu, J., Jin, R., Piroozfar, P., Wang, Y., Kang, B.G., Ma, L., Wanatowski, D., and Yang, T. (2018). "An Initiated BIM Climate-based Framework Incorporating Regional Comparison." Journal of Construction Engineering and Management, in Press, DOI: 10.1061/(ASCE)CO.1943-7862.0001568.

Xue, H., Zhang, S., Su, Y., Wu, Z., and Yang, R.J. (2018). "Effect of stakeholder collaborative management on off-site construction cost performance." J. Clean. Prod., 184, 490-502.

Yan, M., Zhao, F., Tian, J., Li, C., and Guo, N. (2014). "Introduction of construction organization management and technology system of assembly concrete structure." Engineering Quality. 32(6), 13-18. (In Chinese)

Yang, C. (2011). "Study on quantitative risk analysis of the overseas projects." Master Thesis. Shanghai Jiaotong University, Shanghai, China. 20-22.

Yuan, H. (2013). "A SWOT analysis of successful construction waste management." J. Clean. Prod. 39, 1-8. http://dx.doi.org/10.1016/j.jclepro.2012.08.016. 
Yunus, R., and Yang, J. (2014). "Improving ecological performance of industrialized building systems in Malaysia." Construction Management and Economics, 32, 183-195.

Zhang, X., Shen,L.Y., and Tsui, Y. (2012). "Policy risks in developing the housing product process: a holistic perspective." J. Clean. Prod., 53, 47-55.

Zhang, X., Skitmore, M., and Peng, Y. (2014). "Exploring the challenges to industrialized residential building in China." Habitat International, 41, 176-184.

Zhao, Q. (2017). "Key points of precast structure construction deep design." Construction Technology. 46(4), DOI: 10. 7672 /sgjs2017040021. (In Chinese).

Zou, X.W., and Zhang, G. (2009)."Managing risk in construction projects: life cycle and stakeholder perspectives.” Int. J. Constr. Manage., 2, 61-77

\section{Appendix: Questionnaire Survey on risk perceptions towards implementing off-site construction in integrated design \& construction project delivery}

\section{Part One: Background and Experience of survey participants (single choice)}

1. Your organization. A. Architectural \& engineering design firms B. Building contractor C. Housing developer $\quad$ D. Academic institutions E. Others (Please specify).

2. Please describe your experience level in off-site construction projects. A. with sufficient practical experience working in OSC projects; B. with certain knowledge but limited practices in OSC projects; C. with limited knowledge in OSC projects; D. with little knowledge or experience in OSC

3. Please describe your experience level integrated design \& construction projects. A. with sufficient practical experience working in IDC project delivery; B. with certain knowledge but limited practices in IDC project delivery; C. with limited knowledge in IDC projects; D. with little knowledge or experience in IDC

4. In your opinion, would OSC projects be more widely applied in China's building industry in the near future? A. Yes, OSC has significant advantages over traditional cast on-situ construction; B. No, due to multiple barriers such as higher cost and lack of technical standards; C. Others (please specify).

5. Which of the following statements best describes your opinion towards applying IDC in OSC projects? A. OSC and IDC could complement each other to reduce project risks; B. The project risks are increased due to the uncertainties brought by both OSC and IDC; C. It is hard to tell the risks by applying IDC in OSC projects.

Part Two: Likert-scale question of probability and severity of risks involved in OSC projects adopting IDC project delivery approach

Please not that the definitions for the numerical scales of probability in Question 6 and severity in Questions 7 were also provided during the questionnaire survey as consistent with Table 2.

6. Please rank the probability of risks that may occur in OSC projects adopting IDC. The numerical choices are 1-5 (1. Almost impossible; 2. Unlikely; 3. Occasionally; Likely; 5. Very often)

\begin{tabular}{|c|c|c|c|}
\hline Risk item & Description & $\begin{array}{l}\text { Probab } \\
\text {-ility }\end{array}$ & Severity \\
\hline Law, policy, and regulation & $\begin{array}{l}\text { Insufficiently developed regulation and policies to promote OSC } \\
\text { (e.g., lack of incentive policy from the government) }\end{array}$ & & \\
\hline Resilience performance & $\begin{array}{l}\text { Uncertainty of prefabricated structure in resisting natural } \\
\text { disasters and its resilience performance }\end{array}$ & & \\
\hline $\begin{array}{l}\text { Design incorporating the } \\
\text { local condition }\end{array}$ & $\begin{array}{l}\text { Insufficient consideration of the local supply chain condition in } \\
\text { the design stage }\end{array}$ & & \\
\hline Design experience of & Insufficient experience of architects and engineers in designing & & \\
\hline
\end{tabular}




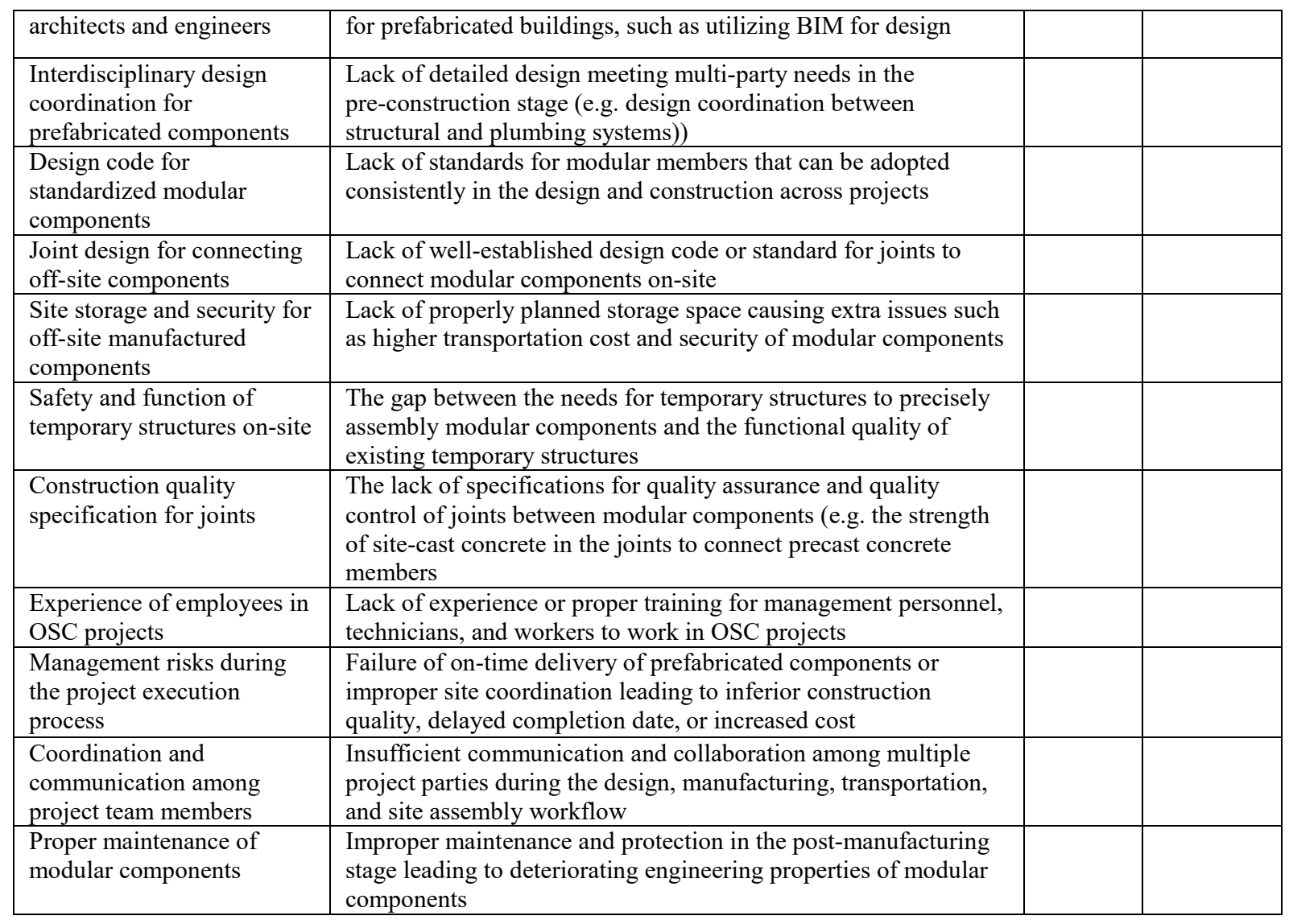

7. For the same risk items listed in the last question, please rank the severity of risks that may occur in OSC projects adopting IDC. The numerical choices are 1-5 (1. negligible;
Less significant;
3. Significant;
4. Critical;
5. Disastrous)

2. 